\title{
DISSERTAÇÕES DE MESTRADO
}

1994 
ANELLI, Luiz Eduardo

Pelecipodes da Formaçâo Piauí (Pensilvaniano Médio), Bacia Parnába, Brasil. 05 de maio. 160p. Orientador: Antonio Carlos Rocha-Campos.

Resumo: Descrevem-se 21 táxons de pelecipodes provenientes de três fácies carbonáticas da parte superior da Formação Piauí (Pensilvaniano Médio), aflorantes na região nordeste da Bacia do Parnaíba. Duas novas espécies (Schizadus mocamboensis e Oriocrassarella piauiersis) são propostas e sete gêneros examinados permanecem ainda indeterminados, aguardando a obtenção de material de melhor preservação. Por outro lado, quatro táxons identificados $\mathrm{cm}$ estudo anterior nâo foram localizados nas coleçōes estudadas.

Os calcários fossiliferos estudados (Mocambo, Contendas e Meruóca) sâo denominados a partir de fazendas da regiăo, onde se localizam pedreiras para extraçăo de calcário. Nesses locais os carbonatos ocorrem associados a argilitos, siltitos e arenitos. As relaçôes estratigráficas entre as diversas ocorréncias $e ́$ ainda pouco conhecida. De modo geral, considera-se que os sedimentos ter-se-iam depositado $\mathrm{cm}$ ambiente marinho raso, de plataforma carbonática, ou lagunar.

Além de pelecípodes (56\%), espécies de macroinvertebrados marinhos atualmente reconhecidas nas assembléias incluem: braquiopodes $(23 \%)$, gastropodes $(10 \%)$, trilobites $(5 \%)$, cefalópodes (3\%) e briozoários (3\%). A fauna é, portanto, dominada pelos moluscos $(69 \%)$. Dentre os microfósseis, são abundantes os foraminiferos arenáceos e calcarios, conodontes, fragmentos de crinóides e equinodermos e ostracodes, sendo mais raros os escolecodontes, espículas de esponja, fragmentos de peixes e restos vegetais.

A análise tafonômica da fauna sugere que as formas da infauna profunda foram preservadas in situ, possivelmente pelo aumento relativamente brusco da taxa de sedimentação, enquanto as formas da epifauna, semi-infauna, e da infauna rasa e intermediária, sofreram remobilização, com transporte lateral das conchas relativamente pequeno e rápido soterramento.

Quanto ao hábito de vida, os pelecipodes subdividem-se em: escavadores rasos (47\%), epifauna bissada $(26 \%)$, escavadores profundos $(11 \%)$, semi-infauna bissada $(11 \%)$ e escavadores intermediários $(5 \%)$.

O predomínio absoluto de formas suspensivoras (91\%) sobre as formas detritivoras ( $9 \%$ ), dentre os pelecípodes, associadarnente às feiçōes tafonômicas da assembléia, sugere um substrato bentônico marinho, pelo menos moderadamente agitado. A presença frequüente de invertebrados estenohalinos na assembléia, evidencia um nivel de salinidade normal, durante a deposição das fácies Mocambo, Contendas e Meruóca.

Fatores físicos e ecológicos, tais como, batimetria, nivel de oxigénio dissolvido na água, salinidade, presença de predadores etc., podem ter sido determinantes na composiçăo da assemblëia da Formação Piaui.

Várias caracteristicas das assembléias estudadas permitem interpretá-las como tipicamente "tetianas" e afins a outras assembléias do norte da América do Sul, e do sul da América do Norte. Dentre as mais importantes, destacam-se a presença de muitos dos táxons típicos (e.g., Wilkigia, Permophorus, Astartella, Pteronites), a associação com vários indicadores paleoclimáticos biológicos e sedimentológicos compativeis com a posição paleolatitudinal da parte norte da América do Sul próxima ao Equador, durante o Neocarbonifero.

Abstract: Twenty-two taxons of pelecypods are described from assemblages found in three carbonatic facies of the upper part of Piauí Formation, Middle Pensilvanian (Marrowan-Atokan), Parnaiba Basin, Brazil. Two new species (Schizodus amazonicus sp. n., Oriocrassatella piauiensis sp. n) are proposed; seven genera remain undetermined, until better preserved material is found; four taxons identified in previous work were not found in the collections examined.

The carbonatic facies (Mocambo, Contendas and Meruóca) have been named after the farms where quarries for extraction of the carbonates are located. They occur associated with mudstones, siltstones and sandstones and are interpreted as having been deposited on shallow marine carbonatic shelf, or lagunar environments.

Besides the pelecypods ( $56 \%$ ), other marine macroinvertebrates from the Piaui Formation include: brachiopods $(23 \%)$, gastropods $(10 \%)$, trilobites $(5 \%)$, cephalopods $(3 \%)$ and bryozoans $(3 \%)$. The assemblage is, thus, dominated by mollusks $(69 \%)$. Among the microfossils, arenaceous and 
calcareous foraminifers, conodonts, crinoid and echinoderm fragments, and ostracods are abundant. Sponge spicules, scolecodonts, fish and plant fragments are rarer.

Taphonomic analysis of the assemblage indicates that pelecypods from the deep infauna were preserved in situ, possibly by a relatively sudden increase in the sediment rate, while the epifaunal, semi-infaunal, and shallow and intermediate infaunal taxons, were reworked during relatively short lateral transport, being rapidly buried.

According to their life habits the pelecypods studied are subdivided into: shallow burrowers $(47 \%)$, byssate epifaunal $(26 \%)$, byssate semi-infaunal $(11 \%)$, deep burrowers ( $11 \%)$ and intermediate burrowers (5\%). Dominance of suspensivorous elements among the pelecypods $(91 \%)$, associated with taphonomic characteristics point out to a marine benthic substrate of moderate energy. The high frequency of stenohaline invertebrates in the assemblage indicates normal salinity during the deposition of the Mocambo, Contendas and Meruóca facies.

Physical and ecological features, like bathymetry, level of dissolved oxygen. salinity, presence of predators, etc., may have been the leading factors in determining the composition of the invertebrate assemblage of the Piaui Formation.

Several features of the fauna studied indicate typical "tethyan" affinity. Among these are the occurrence of typical taxons (e.g., Wilkingia, Permophorus, Astartella and Pteronites) and of sedimentological, paleoclimatic and biological indicators of a low (Equatorial) paleolatitudinal position of the Parnaiba Basin in the Late Carboniferous.

\section{CONDE, Rita Parisi}

Avaliação das resenvas de $\mathrm{Pb}-\mathrm{Zn}$-Ag do Depósito de Canoas, Municipio de Adrianópolis, PR 28 de novembro. 179 p. Orientador: Jorge Kazuo Yamamoto.

Resumo: A avaliação das reservas de um depósito mineral é um procedimento que tern por objetivo estimar a quantidade e qualidade do minério, dando subsidios aos estudos econômicos, de planejamento de lavra e beneficiamento.

Existem diversos métodos de avaliação de reservas, que podem ser divididos $\mathrm{cm}$ dois grupos principais: métodos clássicos e métodos computacionais. Esses métodos utilizam-se de diferentes princípios de interpretaçăo, e técnicas matemáticas de interpolaçāo, que devem permitir uma melhor estimativa de valores de variáveis de interesse, em pontos năo amostrados da pesquisa mineral.

Esses diferentes métodos de cálculo foram aplicados no estudo de um caso no Depósito de Canoas, Municipio de Adrianópolis (PR).

o Depósito de Canoas é representado por um corpo lenticular, alongado, do tipo estratiforme; a mineralização ocorre sob a forma de disseminações de sulfetos (galena, esfalerita, pirita) $\mathrm{em}$ rochas carbonáticas. Este depósito é compartimentado $\mathrm{em}$ dois corpos (Canoas 1 e Canoas 2) por uma erosão na sua porção média sendo que, para fins de avaliação de reservas foram utilizados os dados referentes a Canoas 2, levantados durante o inventário dos dados da pesquisa mineral e caracterizados durante a etapa de análise de dados. Os métodos clässicos utilizados foram perfis padräo, perfis lineares, poligonos e triângulos e, os computacionais, foram inverso da poténcia da distância (IPD) e krigagem ordinária (KO).

Os resultados obtidos para a Mina de Canoas 2 indicam que os métodos aplicados não apresentam diferenças significativas na avaliaçăo das reservas medidas ou teores médios. As diferenças obtidas, entre estes métodos, podem ser atribuidas às diferenças de áreas entre os métodos considerados. Esta relativa similaridade dos resultados é função do tipo de depósito (estratiforme), espessura e teores regulares, e amostragem (malha regular).

A utilização de um método de avaliação de reservas que produza resultados de qualidade deve ser funçăo dos aspectos geológicos dos depósitos e da determinação de medidas de erros associados às estimativas.

$\mathrm{Na}$ impossibilidade da utilização da KO (não obtençăo de variogramas significativos), é possivel a utilização do IPD seguido dos métodos clássicos, uma vez que dependendo do tipo de depósito, estes podem produzir boas estimativas.

Abstract: Ore reserve estimation is a technical procedure which attempts to evaluate a mineral 
deposit and provide the necessary information regarding economical feasibility, planning, and ore processing.

Basically, the ore reserve estimation methods are the classical and computational methods which utilize different principles of interpretation and mathematical interpolation functions. Both try to establish the best estimation of the interest variable in points which were not sampled.

These different ore reserve estimation methods were applied to the lead-zinc deposit of Canoas, municipality of Adrianópolis, state of Paraná, southern Brazil.

The Canoas deposit is represented by a long lenticular stratiform body, the mineralization occurs in sulphide disseminations (galena, sphalerite, pyrite) in carbonate rocks. This deposit is divided into two parts (Canoas 1 and Canoas 2) separated by erosion. The data set used for ore reserve estimation in Canoas 2 was taken from the data inventory of mineral exploration and characterized during the data analysis phase. Classical methods employing cross-sections, polygons, and triangles were used, while computational methods include inverse of weighting distance and ordinary kriging.

The ore reserve estimation methods applied in this case did not present significant differences in ore reserves or average grades. The differences that were observed between these methods can be attributed to differences in the size of the computed areas. This relative similarity of the results is a function of deposit type (stratiform) and the regular thickness, grade, and sampling.

\section{FERRARI, Viviane Carillo}

Estudo mineralógico e geoquímico dos minérios fosfatados de Irecê-BA. 06 de setembro. $76 \mathrm{p}$. Orientador: Adolpho José Melfi.

Resumo: As mineralizaçōes fosfatadas estudadas, localizadas próximas a cidade de Irecê, no centro oeste do Estado da Bahia, ocorrem associadas a niveis estromatolíticos encaixados nas rochas carbonáticas do Grupo Una, do Proterozóico Superior ( $\neq 600 \mathrm{Ma})$. As camadas apresentam-se localmente deformadas, posicionadas subverticalmente. Foram caracterizados quatro tipos de minérios, um primário, estromatolítico e três outros secundários ("casa de abelha", "cascalho" e "rolados") formados pela alteração intempérica das rochas mineralizadas ou do minério primário.

Os tipos "casa de abelha" e "cascalho" representam as fácies de alteração do minério primário encontrados associados, normalmente, em um mesmo perfil de alteração sob condiçôes climáticas atuais. $\mathrm{O}$ intemperismo leva a um enriquecimento em $\mathrm{P}_{2} \mathrm{O}_{5}$ por lixiviaçäo dos carbonatos $\mathrm{e}$ preservação das apatitas. Nestes tipos ocorre também um enriquecimento em ETR com o intemperismo. Apesar de sua alta estabilidade nas condiçōes atuais, que săo relativamente brandas, a apatita, único mineral portador de fósforo destas fácies, apresenta algumas feiçōes de dissoluçāo. Análises detalhadas ao $\mathrm{RX}$ e IV, revelam que a apatita do perfil é do tipo Iluoroapatita empobrecida em $\mathrm{CO}_{2}, \mathrm{com}$ pequenas variaçōes estruturais, ao longo do perfil.

O minério fácies "rolados", do tipo nodular e do tipo brecha, é constituído de fragmentos estromatolíticos (com ou sem córtex aluminoso) cimentados por uma matriz aluminofosfatada (millisita). Os vazios são preenchidos por fosfato aluminoso da familia da crandallita, apatita secundária, caolinita e gibbsita. As apatitas secundárias do tipo fluorapatita sofrem uma pronunciada dissoluçăo. A fácies "rolados" é formada pela evolução superficial do minério primário em condições tropicais mais úmidas, laterizantes e que certamente ocorreram em épocas anteriores.

Abstract: The phosphate ore of Irece, in the center-west of Bahia State, occurs associated with stromatolitics levels. The area of study insert in the sequence of carbonate rocks of Una Group, Upper Proterozoic $( \pm 600 \mathrm{Ma})$.

The study permitted to characterize four kinds of ore, one primary, stromatolitic, and other three secondary, "Casa de Abelha", "Cascalho" and "rolados", formed by the weathering alteration of mineralized rocks.

The "casa de abelha" and "cascatho" ores represent the alteration facies of primary ore under actual climatic conditions. The weathering induces to enrichment in $\mathrm{P}_{2} \mathrm{O}_{5}$ content by leaching of carbonates and preservation of apatites. In these kinds a enrichment in ETR due to weathering, also occurs. Apatite, the only phosphated mineral of those facies, show, although its high stability in the actual conditions, relatively mild, may present some features of dissolution. Analysis from RX and IV, reveal 
that the apatite's profile is the fluorapatite impoverishes in $\mathrm{CO}_{2}$ contert, with small structural variations.

The ore facies "rolados", nodular kind and breccia kind, constituted of stromatolitics fragments (with or without aluminous coating) cernented by a aluminum phosphate groundmass (millisite) with voids filled by mineral of crandallite family, apatite, caolinite and gibbsite. High dissolution can occur in the secondary apatites kind fluorapatite. The "rolados" facies was formed by evolution superficial of primary ore in a wet, tropical climate, in lateritic weathering zone and they surely did occur in age ago.

FERREIRA, Nelson Luiz Schleder

Aspectos da geoquimica ambiental da Mina de Rocha-PR. 09 de junho. 94p. Orientador: Franco Levi.

Resumo: $\quad$ O presente trabalho procurou analisar a disseminaçâo dos metais pesados na drenagem. oriundos das atividades de uma empresa de mineracão de chumbo localizada às margens do ribeirăo do Rocha, afluente do rio Ribeira de Iquape, na divisa dos Estados do Paraná e Sāo Paulo.

Foram realizadas análises para chumbo, cobre e zinco nos sedimentos de fundo (fraçào < $2 \mu \mathrm{m}$ ) e águas superficiais. Os sedimentos foram submetidos a abertura ácida forte (concentraçōes totais) e análise química seqüencial, o que juntamente com o levantamento dos principais parâmetros fisicoquímicos das águas, permitiram a precisa identificação dos focos de contaminação da drenagem $e$ as principais associaçōes dos metais pesados com o material particulado (transporte), cujas preferências encontradas foram entre os oxidróxidos de ferro e manganés e os carbonatos. Em todos os pontos amostrados foram ultrapassados os limites toleráveis para os metais pesados em questão nos sedimentos.

Realizaram-se também análises para a dosagem de chumbo nos cabelos do escalpo de crianças moradoras das imediaçōes da mineraçāo. Os resultados mostraram que apesar das concentraçōes encontradas estarem dentro do limite tolerável, pode estar ocorrendo a incorporação do chumbo via ingestão (intestinal) nos individuos amostrados.

Abstract: $\quad$ The purpose of this work is to study the dispersion of heavy metals from lead mining on the Rocha stream tributary of the Ribeira de Iguape river at the border of the States of Säo Paulo and Paraná.

Lead, copper and zinc were determined in the bottom sediments (fraction $<2 \mu \mathrm{m}$ ) and superficial waters. The sediments were analyzed by strong acid dissolution methods (total concentrations) and sequential chemical analysis, that together with the study of the main physico-chemical parameters of waters, allows us to identify contamination points within the drainage by means of heavy metals associations with particulate matter (transported); preferential associations were with iron and manganese oxide/hydroxides and carbonates. Every analyzed sample contained concentrations of the mentioned sedimentary heavy metals corresponding to levels way beyond tolerable limits.

Lead determinations were also obtained for the hair of children living in the vicinities of the mining activities. Results should that in spite of the fact that the values were within the tolerable limits there may be a substantiable addition of lead to the living tissues of the sampled individuals by intestinal absorption.

\section{FIGUEIRA, Joảo Leandro Gandar}

Eficiência agronómica do termofosfato potássico fundìdo: estudo experimental em "Casa de Vegetaçäo", campo e colunas de İxiviação. 12 de dezembro. 70 p. Orientador: José Vicente Valarelli.

Resumo: Experimentos em casa de vegetação, tendo como substrato solo de uma área de cerrado đa regiāo de Sorocaba-Itapetininga e como culturas soja e milho, procuraram estabelecer relaçōes de produtividade comparando-se o efeito dos componentes termofosfato potássico fundido (TKF), superfosfato simples (SSP) e superfosfato triplo (TSP) como fontes unicamente de fósforo, em adição a potássio, nitrogénio e enxofre, como fontes de NPK. Esses fertilizantes foram adicionados em vasos com $2 \mathrm{~kg}$ de solo, empregando-se $150 \mathrm{mg} \mathrm{P} / \mathrm{kg}$ de solo $\mathrm{cm}$ ambos os experimentos. No caso do NPK, o teor dos demais elementos guardava uma relaçāo $\mathrm{N}_{2} \mathrm{P}_{2} \mathrm{O}_{5}: \mathrm{K}_{2} \mathrm{O}$ de $4: 14: 8$. Além disso, foi feito também um segundo plantio das mesmas culturas nos mesmos vasos, porém, sem fertilizaçăo adicional. 
A produção de matéria seca mostrou que o TKF sem adições é equivalente aos fertilizantes solúveis em água, com importante efeito residual no segundo plantio para a soja. Para o milho, a produçào com TKF foi superior à dos demais fertilizantes no primeiro plantio, aumentando no segundo.

A adição de $\mathrm{K}, \mathrm{N}$ e S aumentou ligeiramente a produção com TKF, obtendo-se melhores resultados com TSP e SSP no primeiro plantio em ambas culturas. No segundo plantio, a produção com os fertilizantes foi nivelada a valores baixos semelhantes aos da testemunha.

Experimentos de lixiviação do mesmo solo, fertilizado com TKF, SSP e TSP em série fosfätica e série NPK em gomo superior de coluna de lixiviaçāo aquosa, mostraram grande fixação de P proveniente das fontes solúveis, paralelamente ao $\mathrm{K}$ e Ca. O P do TKF quase näo apresentou fixaçăo. Experimentos semelhantes foram efetuados com "solos artificiais" constituidos por concentrado de caulinita, bauxita natural e concreção limonítica natural, e comparando-se duas fontes fosfatadas, TKF e SSP. Os resultados evidenciaram grande fixação de fósforo proveniente do SSP e pequena do TKF. Foi possivel caracterizar uma fixação sob forma insolúvel em água e solúvel em ácido citrico (adsorção e nucleaçāo) e sob forma de composto estável, insolúvel em ácido citrico sobretudo da fonte SSP. A fixação fol maior na limonita, seguindo-se a bauxita ferruginosa e, por último, a caulinita.

Dois plantios de milho foram realizados em Latossolo Vermelho Amarelo com calagem com fertilizaçăo TKF, TMgF (termofosfato magnesiano fundido) e SSP (série pura), e com adição de $\mathrm{N} e$ K (série NPK) somente no primeiro plantio. Os resultados não favoreceram o TKF em relação aos demais fertilizantes. de grãos de milho.

Em área nova, sem calagem e fertilizaçăo fosfática, o TKF apresentou melhor produção

\begin{abstract}
This thesis reports about the experiments carried out both in a green house and in the field, in order to compare the agronomic efficiency of conventional fertilizers (soluble in water) and thermo-phosphate fertilizers (not soluble in water).

The first experiment took place in a green house, with pots containing savanna soil from the Sorocaba-Itapetininga region, under soy-bean and corn culture. Compared were the effects of the application of "smelted potassium-thermo phosphate" (TKF), simple super-phosphate (SSP), and triple super-phosphate (TSP), as sources of phosphate only, whereas to other pots potassium, nitrogen and sulphur was added as sources of NPK.
\end{abstract}

To correlate the results, a reference standard was used (without any fertilizer). All fertilizers were added to pots containing $2 \mathrm{~kg}$ soil, using $150 \mathrm{mg} P$ per $\mathrm{kg}$ soil for all experiments. The relation between the elements $\mathrm{N}: \mathrm{P}_{2} \mathrm{O}_{5}: \mathrm{K}_{2} \mathrm{O}$ in $\mathrm{NPK}$ was as $4: 14: 8$. A second planting was carried out in the same pots, with the same crops, without additional fertilizer.

Resulting, there was no change in the production of dry material, which shows that TKF without addition of NPK is equivalent to water-soluble fertilizer.

The second soy-beans planting showed a significant residual effect. In the first com plantation, the production with TKF was higher than the one with SSP and TSP. The second com plantation, because of the residual effect, showed an even higher production.

The addition of $\mathrm{K}, \mathrm{N}$ and $\mathrm{S}$ slightly increased the production with TKF, and resulted in better results with TSP and SSP in the first planting under both cultures. In the second planting, the production with fertilizers was levelled to lower values similar to those of the reference standard.

In the second experiment columns for leaching were used, with the same soil, fertilizer with TKF, SSP and TSP in the phosphatic series and series of NPK in the upper section of the watery leach-column, showing a large fixation of $\mathrm{P}$ coming from the soluble sources, parallel to $\mathrm{K}$ and $\mathrm{Ca}$. The $\mathrm{P}$ of the TKF did hardly show fixation. In a second phase similar experiments were carried out, using artificial soil of kaolinite, ferruginous bauxite and ferruginous limonite concretions, and comparing two phosphate sources, TKF and SSP. The results demonstrated large fixation of phosphorus coming from the SSP and little from TKF. It was possible to characterize a certain fixation under the in water insoluble form and soluble in citric acid (adsorption and centering) and under the form of stable compost, insoluble in citric acid mainly from the SSP source. The fixation was larger in limonite following bauxite and, lastly, kaolinite.

The third experiment was carried out in the field. Two plantations of com were realized in a reddish-yellow Latosol with setting ("calagem"), fertilizer with TKF, TMgF (smelted thermo- 
phosphate manganese) and SSP (pure series). Only in the first plantation N and K (NPK series) was added. The results are not in favor of TKF in relation to the other fertilizers.

Also in the field, in another area, without setting and phosphate fertilizer, the use of TKF presented better production of com grains.

In conclusion, these experiments show in general that the use of TKF presents advantage. It shows that the adding of setting masks this advantage because it changes the necessary acid pH for a good performance of TKF.

\section{GANDINI, Antonio Luciano}

Mineralogia, inclusāes fluidas e aspectos genéticos do topázio imperial da região de Ouro Preto, Minas Gerais. 16 de dezembro. 212p. Orientador: Darcy Pedro Svisero.

Resumo: O topázio imperial da regiåo de Ouro Preto, Minas Gerais, ocorre sob a forma de cristais prismáticos, sendo raros os exemplos biterminados, Apesar de normalmente ocorrerem sob a forma de agregados e fragmentos, predominam os tipos idiomórficos constituídos de um prisma rômbico vertical terminado por uma bipirâmide rômbica. As dimensōes variam desde alguns milimetros até $20 \mathrm{~cm}$ aproximadamente, predominando a faixa em tomo de 1 a $4 \mathrm{~cm}$. As análises dos parämetros de cela unitária mostraram que 0 ao varia de 4,615 a $4,656 \AA$, bo de 8,747 a $8,815 \AA, c_{0}$ de 8,375 a $8,412 \AA$ e 0 volume $(V)$ da cela unitária de 340,639 a $343,823 \AA$. A cor, uma das propriedades mais notáveis desse mineral-gema, varia de amarelo-dourado a vermelho-conhaque, apresentando matizes transicionais entre esses dois tipos. Análises quimicas de topázios coloridos obtidas a partir de microssonda eletrónica indicaram ser $\circ \mathrm{Cr}^{3+}, \mathrm{V}^{3+}$ e $\mathrm{Fe}^{3+}$ os possiveis cromoforos deste mineral-gema. Para os topázios da regiăo de Ouro Preto, o teor médio de $\mathrm{SiO}_{2}$ é de $32,50 \%$, o de $\mathrm{Al}_{2} \mathrm{O}_{3} 54,90 \%$ e o F-16,00\%. Com relaçalo aos indices de refração, $\mathrm{nX}$ varia de 1,615 a $1,628, \mathrm{nY}$ de 1,618 a 1,631 e $\mathrm{nZ}$ de 1,625 a 1,639 ; a birrefringência, por sua vez, aria de 0,008 a 0,015 . O valor do ângulo $2 \mathrm{~V}_{2}$ varia de 62 a $67^{\circ}$. $\mathrm{A}$ densidade relativa está compreendida no intervalo de 3,40 a 3,59 . As inclusōes cristalinas foram estudadas principalmente por difração de raios X e pelo microscópio eletrônico de varredura, sendo representados por carbonatos, topázio, hematita, ilmenita, mica, rutilo, quartzo, tremolita, euclásio, cloritóide e apatita. Estas ocorrem em número bem menor em relaçăo às inclusōes fluidas, que são bem mais frequlentes e abundantes. As inclusōes fluidas sāo predominantemente bifásicas a $25^{\circ} \mathrm{C}$, sendo constituídas essencialmente por soluçōes aquosas salinas mais $\mathrm{CO}_{2}$. Elas foram estudadas por vários métodos (platina de aquecimento/resfriamento, espectroscopia de infravermelho e espectroscopia micro Raman), que permitiram a identificação de suas composiçōes: água, gás carbônico, nitrogênio e hidrocarbonetos $\left(\mathrm{CH}_{4}\right)$. A temperatura minima média de formação dessas inclusões $\varepsilon$ de $300^{\circ} \mathrm{C}$, com a pressâo média variando cntre 2.000 a 3.000 bar.

As ocorrências primárias de topázio imperial da região de Ouro Preto estão relacionadas a rochas carbonáticas do Supergrupo Minas, pertencente ao Quadrilátero Ferrifero. Entre os litotipos principais, podem ser citados os filitos carbonáticos que transicionam para mármores impuros, tanto lateralmente como verticalmente. As mineralizaçós de topázio imperial ocorrem em veios centimétricos e descontínuos nessas rochas, e estào associadas a uma zona de falhas normais em bloco, resultante de um processo de distensăo, apresentando direção predominante $\mathrm{N} 60^{\circ} \mathrm{W}$. Estas falhas foram, provavelmente, reativadas durante um evento tectônico no final do Cretáceo ou inicio do Terciário, dando origem a vários focos de vulcanismo, que produziram soluçôes saturadas em silica. Não se observa nenhuma feição de metamorfismo nessas rochas vulcảnicas.

As rochas metamórficas encaixantes e os veios mineralizados encontram-se intensamente decompostos. Contudo, nessas litologias podem ser observadas algumas de suas estruturas antigas a a presença de certos minerais primários como quartzo, hematita, topázio, pirofilita, rutilo, euclásio e sericita. O topázio normalmente é encontrado em massas de caulim e nos produtos de decomposiçầo de niveis carbonáticos, denominados pelos garimpeiros de "borra de cafe".".

Os dados microtermometricos indicam que a gènese do topázio imperial da regiāo de Ouro Preto está relacionada a processos hidrotermais. Temperaturas de homogeneizacão total por volta de $300^{\circ} \mathrm{C}$ e isócoras construidas a partir das composiçōes das inclusōes fluidas, revelaram pressōes da ordem de 2,5 kbar sugerindo portanto um ambiente hidrotermal de pouca profundidade. 
Abstract: The imperial topaz of the Ouro Preto area, in the State of Minas Gerais, occurs in the form of prismatic crystals. Doubly terminated samples are rare. Although these topazes usually occur as aggregates and fragments, idiomorphic types predominate. They consist of a vertical rhombic prism terminated by a rhombic dipyramid. The size varies from a few millimeters to approximately $20 \mathrm{~cm}$, with a predominance of the range 1 to $4 \mathrm{~cm}$. Analyses of the parameters of the unit-cell presented the following value variations: $a_{2}=4.615$ to $4.656 \AA, b_{0}=8.747$ to $8.815 \AA, c_{0}=8.375$ to $8.412 \AA$ and $V=$ 340.639 to $343.823 \mathrm{~A}^{3}$. The color, one of the most spectacular properties of this gem-mineral, varies from goiden yellow to dark reddish sherry, showing transitional hues between these two types. Chemical analyses of colored topazes obtained by electron microprobe techniques indicated that $\mathrm{Cr}^{3+}, \mathrm{V}^{3+}$ and $\mathrm{Fe}^{3+}$ are the possible cromophores of this gem-mineral. The average rate of $\mathrm{SiO}_{2}$ was $35.50 \%, \mathrm{Al}_{2} \mathrm{O}_{3}$ was $54.90 \%$ and $\mathrm{F}$ - was $16.00 \%$. The refractive index presented a certain range of variation, in which $\mathrm{nX}=$ 1.615 to $1.628, \mathrm{nY}=1.618$ to $1.631, \mathrm{nZ}=1.625$ to 1.639 and $\mathrm{B}=0.008$ to 0.015 . The value of the angle $2 \mathrm{VZ}$ varied from 62 to $67^{\circ} \mathrm{C}$. The density varied from 3.40 to 3.59 . Crystalline inchusions identified mainly by $\mathrm{X}$-ray diffraction methods as well as by scanning electron microscopy are carbonates, topaz, hematite, ilmenite, mica, rutile, quartz, tremolite, euclase and apatite. Fluid inclusions were identified as predominantly two-phase (saline aqueous solution $+\mathrm{CO}_{2}$ ) at $25^{\circ} \mathrm{C}$, with larger percentage of the liquid phase. Various methods such as cooling/heating, infrared spectroscopy and micro-Raman spectroscopy were used in the study of fluid inclusions. Fluid compositions were identified as water, carbonic gas, nitrogen and hydrocarbonates $\left(\mathrm{CH}_{4}\right)$. The minimum average temperature of formation of the deposits is $300^{\circ} \mathrm{C}$ with an average medium pressure varying from 2,000 to 3,000 bar.

The primary occurrences of imperial topaz in the Ouro Preto area are associated with carbonate rocks of the Piracicaba Group of the Minas Supergroup. These unit vary laterally and vertically with regard to lithology and internal structure. Topaz mineralization occurs in centimeter-scale discontinuous veins and are associated with an extensional fault zone. This fault zone was later reactivated. It predominantly trends $\mathrm{N} 60^{\circ} \mathrm{W}$ and crosses the metamorphic rocks of the Minas Supergroup. This fault was probably related to Cretaceous or Tertiary tectonisms in related to silica-saturated volcanism that occurred in various parts of the region.

The mineralized veins and the host metamorphic rocks are intensely decomposed and only a few original structures and primary minerals such as quartz, hematite, topaz, pyrophyllite, rutile, euclase and sericite are found. Topaz usually occurs in masses of kaolin and in carbonate weathering products called "borra de café" (brown terrena) by garimpeiros.

The topaz is interpreted to have been generated by hydrothermal processes related to the final phase of Late Cretaccous or Early Tertiary volcanism that affected the area.

\section{GLOEDEN, Eiton}

Monitoramento da qualidade da água das zonas nầo saturada e saturada em área de fertimigaçāo com vinhaça. 29 de agosto. 151p. Orientador: José Milton Benetti Mendes.

Resumo: A vinhaça, principal residuo gerado na fabricaçăo de álcool e açúcar, tem sido amplamente utilizada nas lavouras de cana-de-açúcar como uma fonte de nutrientes, principalmente o potássio, substituindo fertilizantes quimicos. Várias pesquisas demonstraram sua eficiência como fertilizante, entretanto são escassas as pesquisas verificando o comportamento dos seus constituintes nas zonas não saturada e saturada.

O principal produtor de álcool e açúcar do Brasil é o Estado de São Paulo, que possui extensas áreas de plantações de cana-de-açúcar, as quais são submetidas constantemente ao processo denominado fertirrigaçăo. Estas plantaçôes estăo localizadas sobre os Aqüliferos Botucatu e Bauru, que sầo os principais do Estado de Säo Paulo.

Este estudo foi desenvolvido em um lugar selecionado sobre a área de afloramento da Formaçāo Botucatu, ocupado com plantaçāo de cana-de-açucar, visando verificar o comportamento dos constituintes da vinhaça nas zonas não saturada e saturada e avaliar os métodos de monitoramento das zonas não saturada e saturada utilizados, em área submetida à fertirrigação.

A área de estudo selecionada foi submetida a uma caracterizaçåo geológica e hidrogeológica utilizando-se amostras de solo elou sedimentos coletadas em sondagens executadas com trados manuais, para determinação da constituição mineralógica e granulométrica das zonas não saturada 
collect hydraulic potential measurements and ground-water samples, for punctual chemical analyses, multilevel monitoring wells were installed.

Tensiometers were installed in order to determine water flux pattern of the unsaturated zone, as well as suction lysimeters to collect water samples to chemical analyses. Panlysimeters were installed in order to evaluate the macropores water flux.

The unsaturated zone water flux data indicated that there are two flux patterns. One which occurs during low rain periods, and another one which occurs during high rain periods.

The first flux pattem shows low water flux values, which may be ascendent or descendent. The second flux pattern shows high water flux values, predominantly descendent.

The study area was subdivided in three areas $(1,2$ and 3$)$ where different rates of vinasse were applied $\left(150,0 \mathrm{e} 330 \mathrm{~m}^{3} / \mathrm{ha}\right)$. The vinasse was submitted to chemical analysis. The parameters used in all chemical analysis were: chloride, dissolved organic carbon (DOC), sulphate, potassium, total Kjeldahl nitrogen (TKN), ammoniacal nitrogen and nitrate nitrogen.

The water quality of unsaturated and saturated zones were altered. The chemical analysis, after the application of vinasse, showed that the parameters DOC, chloride, TKN, ammoniacal nitrogen and sulphate reached concentrations that were above the ground water natural values. In this way, these parameters should be considered in the definition of vinasse application rates. Actually to define application rates of vinasse the parameter utilized is the potassium, which in this research did not determine, as well as nitrate nitrogen, changes on the ground water quality.

The sediments of the Botucatu Formation showed low water retention capacity in the unsaturated zone and high vinasse's constituents transport capacity. The saturated zone showed high ground water velocity values indicating high vinasse's constituents transport. This research demonstrated that, the outcrop area of the Botucatu Formation is very vulnerable to changes on ground water quality characteristics that can be promoted by vinasse application by fertirrigation.

\section{GOMES, Daniel Caminero}

Poluiçăo de aqülfero costeiro de Arembepe-BA por dicido sulfúrico e composios inorgainicos oriundos da produç̃o de dióxido de tilânio. 30 de junho. 116p. Orientador. Uniel Duarte.

Resumo: $\quad 0$ objetivo central deste trabalho é avaliar o impacto às águas subterrâneas devido à disposição não-controlada de residuos sólidos industriais em dunas recentes, assim como vazamentos de ácido sulfürico acidentais ocorridos em indústrias de dióxido de titânio, situada nas proximidades de Arembepe, Municipio de Camaçari, BA. Adicionalmente, pretende descrever os processos envolvidos e as medidas de recuperaçâo ambiental adotadas.

O local foi investigado através de trabalhos de geofisica (sondagens elétricas e caminhamento elétrico), seguidos de instalaçăo de poços de monitoração e cinco campanhas de amostragem/análise quimica de águas, para compostos inorgânicos e parâmetros in situ $(\mathrm{pH}$, temperatura, condutividade elétrica). Foram também realizados ensaios de bombeamento e permeabilidade para caracterizaçăo hidráulica do aquífero local.

Os resultados mostraram a presença de um aquifero principal pouco espesso formado por areias finas, cujas águas subterrâneas movem-se em dois sentidos principais: para o oceano (sudeste) e para o rio Capivara Grande, a noroeste. As velocidades de escoamento săo relativamente altas, entre $60 \mathrm{e}$ $690 \mathrm{~m} / \mathrm{ano}$.

A deposição dos resíduos nas dunas causou um expressivo impacto na qualidade das águas subterrâneas, principalmente devido aos íons sulfato, ferro solúvel e baixos valores de $\mathrm{pH}$, migrando em direçảo ao rio Capivara Grande, principalmente. Os vazamentos e perdas de poluentes na área industrial contribuiram para a formaçăo de uma extensa pluma de poluiçăo em sentido ao oceano.

A acidificaçăo do aqüffero também levou à mobilizaçăo de ions que podem provocar efeitos tóxicos à flora local, como alumínio e manganês.

A poluição atingiu alguns poços rasos, inutilizando-os. Além disso, algumas lagoas sofreram intenso processo de aciđificaçāo, prejudicando a vida aquática.

Para mitigar este impacto, foram implantadas as seguintes medidas de remediação: impermeabilização dos residuos com camadas de argila-bentonita compactadas, protegidas por solo argiloso não compactado $e$ areias das dunas; implantaçăo de poços de bombeamento das águas 
subterrâneas $\mathrm{e}$ bombeamento de uma lagoa interdunas. As águas bombeadas săo enviadas a emissário submarino de $3 \mathrm{~km}$ de distância da costa. Além disso, foi iniciado um trabalho de plantio de espécies nativas.

O pouco tempo de operação do sistema, ainda parcial, impede uma avaliaçăo detalhada quanto à recuperaçăo da área, entretanto, já houve melhoria na qualidade das águas subterrâneas a noroeste da área, provavelmente devido à impermeabilização dos resíduos. Por outro lado, foi constatado um aumento na poluição na área industrial, devido a novas perdas de ácico sulfürico, as quais deveriam ser imediatamente reparadas.

Abstract: The main objective of this work is to evaluate the impact to groundwater quality due to the ancient, uncontrolled disposal of inorganic industrial solid wastes onto sand dunes, together with accidental sulfuric acid leakages, occurred at a titanium dioxide plant, located at Arempebe, Camaçari Country, State of Bahia, Brazil

The region is partially supplied with groundwater wells, some of them being damaged by the contamination. Besides, some lagoons were intensively acidified, with consequent damages to aquatic life.

The study area was investigated by means of geophysical surveys (resistivity, electric soundings and profiles), followed by monitoring wells installation and five water sampling/chemical analysis campaigns, for inorganic compounds. In addition, pumping and slug tests were performed, in order to characterize the local aquifer hydraulic parameters.

Results have shown a sandy aquifer of small thickness, which waters migrate in two directions: towards the occan (southeast) and the Capivara Grande river (northwest), at relatively high seepage velocities: 60 to $690 \mathrm{~m} / \mathrm{yr}$.

The leaching of the solid wastes had provoked high concentrations of sulfate, iron and low $\mathrm{pH}$ values, mainly in direction towards the Capivara Grande river, whereas the industrial pollution plume migrates in direction towards the ocean.

The aquifer acidification has also solubilized some metals that are phyto-toxic, like aluminium and manganese for instance.

The following remedial measures were taken:

solid wastes containment, with mineralogical clay-bentonite covering layers, protected by clayey soil and dune sands;

installation of pumping wells and pumping of a contaminated lagoon to a $3 \mathrm{~km}$ length-outfall into the ocean; and

landscape recovery, using native species.

Due to the short time in operation, the remedial system cannot be evaluated in detail at the moment. However, some quality improvement was achieved at the northwest plume, probably due to the wastes covering system. On the other hand, the plume increased to southeast, due to recent $\mathrm{H}_{2} \mathrm{SO}_{4}$ leakages at the industrial area, which should be immediately repaired.

\section{LANNUZZI, Roberto}

Reavaliaçāo da flora carbonífera da Formaçăo Poti, Bacla do Parnafba. 25 de agosto. 249p. Orientador: Oscar Rösler.

Resumo: A flora da Formaçāo Poti foi estudada preliminarmente por Oliveira $(1934,1935)$ na década de 30. A partir dos anos 50, Dolianiti (1954) descreveu e classificou a maior parte das formas até hoje conhecidas. Oliveira (1934, 1935) e Dolianiti (1954) ressaltaram a afinidade euro-americana desta flora. Em 1962 e 1980, Dolianiti descreve as últimas formas assinaladas para essa flora.

Rigby (1969) é o primeiro a sugerir recombinações taxonômicas de algumas das formas descritas por Dilianiti. Durante os anos 80, alguns outros pesquisadores (Rocha-Campos e Archangelsky, 1985; Césari, 1986 e 1987; Sessarego e Césari, 1989) colocam vários táxons desta flora em sinonímia com formas encontradas em estratos do Neocarbonifero da Argentina. Isto passou a sugerir uma maior afinidade da flora com as floras gondvánicas. No entanto, estas últimas sinonimias foram todas realizadas sem o exame dos espécimes.

Quanto à idade da flora da Formação Poti existe controvérsia: alguns pesquisadores 
indicaram uma idade eocarbonifera (Dolianiti, 1954; Rigby, 1969), outros uma idade neocarbonífera (Oliveira, 1934 e 1935; Archangelsky, 1984 e 1986; Sessarego e Césari, 1989). Rősler e Ciguel (1985) salientaram as afinidades devonianas de algumas das formas da flora, sugerindo assim uma idade um pouco mais antiga. Os estudos palinológicos (Daemon, 1974; Sundaram et al., 1981) têm sempre indicado uma idade eocarbonífera para os estratos da Formação Poti.

Tendo em mente o exposto, a presente dissertação objetivou o reestudo, em nivel sistemático, de todo o material paleobotânico proveniente da Formação Poti e a determinação de sua provável idade. Para tanto, reanalisaram-se o material descrito por Dolianiti $(1954,1962$ e 1980) e aquele coletado, e ainda inédito, de Rösler e Ciguel (1985). Analisou-se também novo material paleobotánico coletado durante trabalho de campo nos Estados do Piaú e Maranhăo. Ainda, coletaram-se e analisaramse palinologicamente os estratos contendo os fitofósseis, e descreveram-se os afloramentos visitados.

O reestudo conclui que a paleoflora da Formação Poti seria composta de pequenas esfenófitas (calamitaceas) e licófitas, pteridospermas do grupo Calamopityales elou Lyginopteridales e prováveis progymnospermas. Algumas novas combinações taxonômicas são também sugeridas e a composição taxonômica passa a ser a seguinte: Diplothmena gothanica (Dolianiti) $\mathrm{n}$. comb., Adiantites sp., Kegilidium lamegoi Dolianiti (1954), Paulophyton sommeri Dolianiti (1954), Paulophyton sp. 1 (n. esp.), Nothorhacopteris sp. 1, Nothorhacopteris sp. 2, Triphyllopteris adtiantotdes n. esp., ?Stamnostoma sp., e uma licófita morfograficamente similar as formas angáricas do gênero Ursodendron (?U. brasiliensis) (Dolianiti) n. comb.

O reestudo taxonômico resultou: a) na redução do número de táxons e espécies previamente descritos; b) na autenticação de várias diagnoses, revelando a existência de um endemismo ao nivel específico; c) na constatação de uma mistura de gêneros gondvânicos com outros cosmopolitas e de uma tendência a endemismo em nível genérico; d) no estabelecimento de afinidades morfológicas com formas do Neocarbonifero da Argentina e, principalmente, com aquelas do eocarbonifero do Peru e Bolivia. eocarbonifera (Viseano?).

Os estudos paleobotânicos e palinológicos revelaram-se mais compativeis com uma idade

O sistema deposicional, inferido a partir do estudo das fácies observadas nos afloramentos donde provieram o novo material paleobotânico, é transicional do tipo planície deltaica.

A composição tafofloristica, o porte dos vegetais e as caracteristicas morfológicas das formas sugerem que a flora teria vivido sob condições de um clima temperado.

As afinidades floristicas com a Flora Paracas, no Peru, e os dados paleoclimáticos, além do posicionamento paleogeográfico, sugerem que a flora da Formaçăo Poti representaria uma extensão a leste do Reino Paraca.

A integração dos dados paleobotânicos, palinológícos, paleomagnéticos, paleogeográficos e paleoclimáticos indica uma possível migraçăo florística intragondvânica durante o Carbonifero. Dentre deste contexto, floras do Neocarbonifero da Argentina e Brasil meridional representariam o registro sulino de floras adaptadas a um clima temperado frio, que já existiam, no final do Eocarbonifero, ao norte do continente, como a da Formação Poti. Estas floras teriam migrado em direção ao sul, em resposta a um controle climático, resultando em considerável diacronismo entre os seus registros.

Abstract: The Poti Formation Flora was studied preliminary by Oliveira $(1934,1935)$ at the thirties. At the fifties, Dolianiti (1954) described and classified most of forms known up to now. Oliveira (1934, 1935) and Dolianiti emphasized the euro-american affinity of this flora. In 1980 Dolianiti described its last two forms.

Rigby (1969) is the first author to suggest taxonomic recombinations to some forms described by Dolianiti. During the eighties some authors (Rocha-Campos and Archangelsky, 1985; Césari, 1986 and 1987; Sessarego and Césari, 1989) synonimized several taxa of this flora in synonimity with forms found out on the Late Carboniferous from Argentina. This fact suggests then a bigger affinity of the Poti Formation Flora with the gondwanic flora. But these synonimies were made without the examination of the specimens.

The age of this flora is uncertain: some authors suggest and Early Carboniferous age (Dolianiti, 1954; Rigby, 1969), others a Late Carboniferous age (Oliveira, 1934 and 1935; Archangelsky, 1984 and 1986; Sessarego and Césari, 1989). Rósler and Ciguel (1985) emphasized the Devonian 
affinity of some forms of this flora, suggesting thus a little more ancient age. The palinological studies (Daemon, 1974; Sundaran, 1981) have always indicated an Early Carboniferous age for the Poti Formation deposits.

Considering what is exposed above, this dissertation objectified: a) the re-study, in systematic level, of all the paleobotanical material related to the Poti Formation Flora, and b) the determination of the probable age of fossil plants. To make it possible, I reanalyzed all the published (Dolianiti, 1954, 1962 and 1980) and unpublished (Rösler and Ciguel, 1985) paleobotanical material collected up to date; collected some new material in the States of Piaul and Maranhâo during the field work; collected samples to palinological study from strata containing fossil plants; and described the studied out-crops.

The re-study indicated that this flora was composed of little sphenophytas (calamitaceas) and licophytas, pteridospermas belonging to the Calamopityales and/or Lyginopteridales group, and possible progymnosperms. Some new taxonomic combinations are also suggest and the taxonomic composition from now on is: Diplotmena gothanica (Dolianiti) n.comb; Adiantites sp.; Kegeliditum lamegoi Dolianiti (1954); Paulophyton sommeri Dolianiti (1954); Paulophyton sp. 1 (n.sp.); Nothorhacopteris sp. 1; Nothorhacopteris sp. 2 (n.form.), Triphyllopteris adiantoides n.sp., and licophyta morphographycally similar to the angara forms that belong to the Ursodendron genera (? U. brasiliensis (Dolianiti) n.comb.).

The taxonomic studies of this flora resulted in: a) the reduction in the number of the taxa and species previously described; b) the authenticity of several original diagnoses, what confirms the existence of endemic species; c) the mixing of the gondwana and the cosmopolitan genera and a trend to endemism in a generic level; d) the establishment of a morphological affinity with forms of the Late Carboniferous from Argentina and, mainly, with those of the Early Carboniferous from Peru and Bolivia.

The results of paleobotanical and palinological studies were most compatible with an Early Carboniferous age (Visean?).

The depositional system was established through facies study of out-crops form which the new paleobotanical material was collected. It is a deltaic plain environment.

The floristic composition, the size of fossil plants and the morphological characters of the forms indicated that this flora could have lived in temperate climatic conditions.

The floristic affinity with Paracas Flora, in Peru, and the paleoclimatic data, besides the paleogeographical position, suggest that the flora could represent an extension eastwards the Paraca Realm record.

The integration of the paleobotanical, palinological, paleomagnetic, paleogeographical and paleoclimatic data indicate a possible intra-gondwanic floristic migration during the Carboniferous. In this context, the Late Carboniferous floras from Argentina and Brazil would represent the south record of floras adapted to temperate or cold climatic conditions, as the Poti Formation Flora, that existed before in the north area of the south-american continent during the end of the Early Carboniferous. These floras would have migrated southwards as an answer to the climatic control, resulting in a considerable diacronism in their records.

\section{MACHADO, Geysa Angelis de Abreu}

Geologia da região e aspectos genéticos das jazidas de esmeraldas de Capoeirana e Belmont, Nova EraItabira, MG. 12 de agosto. 186p. Orientador: Johann Hans Daniel Schorscher.

Resumo: A região das jazidas de esmeraldas de Capocirana e Belmont, Minas Gerais, foi estudada quanto à evolução geológica pré-cambriana e sob aspectos genéticos das mineralizaçōes de esmeraldas. Os métodos de trabalho foram de geologia de campo, incluindo mapeamento $(1: 10.000)$ e amostragens para estudos petrográficos-geoquímicos e mineralógico-cristalográficos.

A área estudada, para a qual é apresentado um mapa geológico em escala $1: 18.000$, é parte do extremo NE do Quadrilátero Ferrífero e, como tal, de evoluçäo arqueo-proterozóica policiclica. No quadro geotectônico regional, situa-se na borda SE do Cráton do Sāo Francisco, em suas porçōes transicionais, entre as partes estaveis do cráton a W, e a faixa móvel policielica do Cinturão Atlântico a E. A evoluçăo geológica compreende estágios arqueanos, representados por associações de gnaisses e granitóides TTG e terrenos granito-greensione belt, e estágios de retrabalhamentos tectono-metamórficos 
proterozóicos. As mineralizaçōes de esmeraldas também se devem a processos arqueanos e proterozóicos.

As rochas TTG, migmatitos (de anatexia), gnaisses metatéticos e metagranitóides polimetamórficos são os litotipos arqueanos mais antigos da região. Ocorrem em corpos restritos preservados dos retrabalhamentos proterozóicos, no interior dos corpos regionais de Granitóides Borrachudos e Metagranitóides Foliados com Fluorita. Sāo rochas, em geral, cinzas claras, hololeucocráticas, ricas em quartzo (per-quartzosas), calcissódicas e levemente córindon-normativas. Incluem ainda tipos mais evoluidos, sodipotássicos e, entre estes, alguns com tendência de granitos tipo A. As rochas da associação TTG são consideradas de origens igneas, orogênicas, e, em termos de análogos modernos, mais similares a granitos de arcos continentais.

As seqüências metavulcano-sedimentares de Capoeirana e Belmont são consideradas mais jovens que as rochas TTG, sendo partes tectonicamente disruptas de um greenstone belt arqueano. Distinguem-se das rochas TTG (polimetamórficas de alto grau) por um hiato metamórfico: foram afetadas por apenas um metamorfismo de baixo grau arqueano (no final da evolução greenstone beli), seguido, no Proterozóico Inferior a Médio, pelo principal metamorfismo regional progressivo, de grau variável - médio a alto - na área estudada. As sequêencias metavulcano-sedimentares compreendem grande variedade litológica, incluindo como tipos essenciais xistos e anfibolitos metaultramáficos, anfibolitos metabásicos a metaintermediários, gnaisses e xistos metavulcano-clásticos, calciossilicáticos e metassedimentares clásticos (derivados de pelitos/siltitos, arenitos líticos e de quartzo-arenitos/quartzitos). Destacam-se, entre outras, como características típicas de greenstone belt arqueano a sucessão litológica geral e, em particular, a natureza extrusiva das rochas metaultramáficas que ocorrem como corpos e/ou niveis delgados (de espessuras de poucos metros a submétricas) concordantes com as demais litologias metavulcano-sedimentares. Estes apresentam, às vezes, pequenas concentrações de cromitas na forma de cromititos disseminados com teores baixos a médios, e sempre anomalias geoquimicas de zinco (várias centenas de $\mathrm{ppm}$ ) que se devem aos teores deste elemento na estrutura das cromitas acessórias e cumuláticas. Os anfibolitos metabásicos e metaintermediários, em sua grande maioria, sâo também de origens extrusivas. Alguns apresentam evidências de alteraçōes hidrotermais-metassomáticas prémetamórficas, sendo cummingtonita-granada-cordierita-anfibolitos, ou ainda, mineralizaçóes de scheelita. As rochas mais preservadas dos processos hidrotermais e mineralizantes indicam filiação oceânica de toleitos de baixo potássio elou de fundo oceânico e, possivelmente, foram gerados em ambiente de bacia retro-arco. As rochas metassedimentares evoluem na sucessão lito-estratigráfica inferida de composiçōes imaturas, com considerável contribuição vulcano-clástica (tipo grauvacas/subgrauvacas) associadas às rochas metavulcânicas máficas, para composiçōes mais maturas, pobres ou isentas destas contribuiçōes, incluindo muscovita-quartzitos, quartzo-muscovita-xistos e raros quartzitos.

$\mathrm{Na}$ fase orogênica, ao final da evolução greenstone belt, a área estudada sofreu em toda a sua extensão retrabalhamentos estruturais e metassomáticos fortes, acompanhados de metamorfismo de grau baixo a, eventualmente, médio, pelo desenvolvimento de zonas de cisalhamento crustais profundas de dimensôes regionais. A combinaçâo destes processos resultou na transformação das rochas TTG em blastomilonito-gnaisses metassomáticos que sāo os Granitóides Borrachudos (GB). Sua composiçăo é de álcali-feldspato-granitos hololeucocráticos com fluorita e carbonato "primário", ricos em quartzo (perquartzosos) e elementos incompativeis, que lhes conferem algumas caracteristicas geoquimicas de granitos tipo A. Destaca-se, sob aspectos metalogenéticos, a presença do $\mathrm{Be}$ que se constitui nestas rochas numa anomalia regional positiva. A composição dos fluidos metassomáticos, indicada pelas composiçōes dos GB e das rochas metaultramáficas metassomatizadas em esmeraldas, foi alcalina, potássica, com evoluçăo para sódica e cálcica, portadora de Be (mais provavelmente, na forma de f́ons complexos com fluoreto e/ou carbonato), $\mathrm{Al}$ e Si, também solúveis em soluçōes alcalinas, entre outros. As reaçöes destes fluidos com as rochas metaultramáficas ricas em elementos cromóforos $(\mathrm{Cr}, \mathrm{V}, \mathrm{Ni}, \mathrm{Fe}$, entre outros) das sequềncias metavulcano-sedimentares de Capoeirana e Belmont originaram nestas, nas zonas de cisalhamento erustal dúctil-rúptil, por processos metassomáticos sinmetamórficos, as mineralizaçōes de esmeraldas de tipo xisto e as mineralizaçōes associadas de tipo veios/mobilizados de quartzo de idade arqueana.

A evolução proterozóica é representada na área estudada principalmente pelo desenvolvimento do principal evento de metamorfismo regional progressivo e deformações associadas. 0 grau metamórfico regional aumenta sistematicamente da fácies xisto verde superior/anfibolito inferior nas extremidades W da área, a anfibolito médio - nos arredores de Belmont, e para anfibolito 
médio/superior - na região de Capoeirana. Este metamorfismo causou o retrabalhamento progressivo dos GB, transformando-os em Metagranitóides Foliados com Fluorita (MGF). Tais transformaçoes foram essencialmente texturais e mineralógicas, preservando nos MGF, entretanto, praticamente na integra, todas as características geoquímicas globais, inclusive a anomalia positiva de Be dos GB. O grau metamórfico regionalmente mais elevado, a $\mathrm{E}$ da jazida de Belmont, iniciou processos de anatexia e fusåo parcial nos MGF produzindo pegmatóides e pegmatitos, alguns destes beriliferos, inclusive portadores de águas marinhas. Pegmatóides intrusivos na sequiência metavulcano-sedimentar de Capoeirana (outrossim, ausentes em Belmont), apresentam-se menos deformados que as encaixantes e podem conter xenólitos (foliados/dobrados) destas em disposição aleatória. Quando intrusivos nas rochas metaultramáficas ş̃o freqülentemente mineralizados em esmeraldas. Estes pegmatóides representam um evento proterozóico de mineralização de esmeraldas, metamórfico, de médio/alto grau, relacionado à anatexia inicial dos MGF. Possivelmente, formaram-se neste evento também as alexandritas de Capoeirana, outrossim, desconhecidas em Belmont, e das quais inexistem, a presente, evidéncias metalogenéticas de mineralizaçōes in situ.

A evolução geológica do Proterozóico Médio e Superior deixou poucos registros mineralógicos-petrográficos na área estudada. Exceçăo deve ser feita a processos locais de rehidratação $\mathrm{e}$ retrometamorfismo fraco, incluindo a formaçâo de epidoto, carbonato, clorita, sericita, que ocorre, principalmente, em zonas de reativação de falhas e fraturas.

Alguns estudos especiais efetuados nas esmeraldas, separando os diferentes tipos de associações genéticas de mineralizaçōes (em xistos, veios de quartzo e veios pegmatóides), indicaram a natureza secundária complexa das inclusōes fluidas estudadas, pela diferença composicional das fases fluidas - sempre ricas em $\mathrm{CO}_{2}$ - em relaçāo aos fluidos dos canais estruturais - sempre pobres em $\mathrm{CO}_{2}$. Indicaram ainda que todas as amostras estudadas pertencem ao grupo de esmeraldas com elevados teores de álcalis.

Abstract: The region of the Capoeirana and Belmont emerald deposits, Minas Gerais, Brazil, was studied with reference to the Precambrian geological evolution and genetic aspects of the emerald deposits. The work methods included field geology and mapping (1:10,000), as well as sampling for petrographic-geochemical and mineralogical-crystallographic studies.

The area, for which a geological map in the scale $1: 18,000$ is presented, is a part of the extreme NE portion of the Quadrilatero Ferrifero (Iron Quadrangle) and of polycyclic Archaean and Proterozoic evolution. In the regional geotectonic framework it is situated on the SE border of the Såo Francisco Craton, in its transitional portions between the stable parts of the Craton in the W and the polycyclic Atlantic mobile belt in the E. The geological evolution comprises Archaean stages represented by associations of TTG gneisses and granitoids, as well as by granite-greenstone belt terrains, which suffered Proterozoic stages of tectonometamorphic reworkings. The emerald mineralizations are also due to both Archaean and Proterozoic processes.

The TTG rocks, anatectic migmatites, metatectic gneisses and metagranitoids are polymetamorphic and the region's oldest rocks. They occur as restricted relict bodies that survived the Proterozoic reworkings, enclosed in the Borrachudos Granitoids and/or the Foliated Fluorite-bearing Metagranitoids, both of regional extent. They are generally hololeucocratic light-gray quartz-rich (perquartzous) rocks of calci-sodic and slightly corundum normative composition. Some more evolved sodi-potassic rocks, amongst which, some tending to A-type granites also occur. The TTG rocks are considered of igneous orogenic origins and, when compared to modern analogues, are more similar to continental are granitoids.

The metavolcano-sedimentary sequences of Capoeirana and Belmont are considered younger than the TTG rocks, representing tectonically disrupted parts of an Archaean greenstone-belt sequence. They show a metamorphic hiatus, when compared to the high-grade polymetamorphic TTG rocks. They were affected by only one low-grade Archaean metamorphism (at the end of the greenstone belt evolution), followed in the lower to middle Proterozoic by the main progressive regional metamorphism, which attained medium to high grades in the studies area. The volcano-sedimentary sequences comprises a large range of lithologies, including, among the essential types, metaultramafic schists and amphibolites, metabasic to metaintermediate amphibolites, gneisses and schists of volcanoclastic calc-silicate and clastic (pelite/siltite, lithic arenites and cuartz-arenite) origins. The general lithological successions are quite typical for Archaean greenstone belts, particularly with respect 
to the extrusive nature of the metaultramafics that occur as concordant rock bodies or horizons of small (metric to submetric) thicknesses intercalated with the other metavolcano-sedimentary lithologies. They sometimes show minor chromite concentrations as disseminated low to medium grade chromitites and always possess geochemical zinc anomalies (in the range of several hundred ppm), the zinc being structurally bound in the chromite lattices. The metabasic and meta-intermediate amphibolites are also mostly of extrusive origins. Some show hydrothermal metasomatic pre-metamorphic alterations, being cummingtonite-garnet-cordierite amphibolites and some even have scheelite mineralizations. The rocks that are best preserved from the hydrothermal and mineralizing processes indicate oceanic origins of low $\mathrm{K}$-tholeiites and/or ocean floor basalts and were possibly formed in the retro-arc basin environment. The metassedimentary rocks evolve in the inferred lithostratigraphic succession from low maturity deposits with considerable volcanoclastic contributions (graywackes/sub-graywackes) to more mature compositions, which are poor in or free of volcanoclastics, including muscovite-quartzites, quartzmuscovite-schists and, rarely, quartzites.

During the final orogenic stage of the greenstone belt evolution the study area as a whole suffered strong structural and metasomatic reworkings accompanied by low to eventually medium grade metamorphism in the course of the development of deep crustal shear zones of regional extent. The combination of these processes resulted in the transformation of the TTG rocks into metasomatic blastomylonite gneisses, the Borrachudos Granitoids (GB). They are hololeucocratic quartz-rich (perquartzose) alkali feldspar granites with fluorite and "primary" carbonate, rich in incompatible elements. These give the GB some geochemical characteristics of A-type granites. Concerning the metallogenetic aspects, the presence of $\mathrm{Be}$ is relevant; in the $\mathrm{GB}$, it characterizes a positive geochemical anomaly of regional extent. The composition of the metasomatisc fluids, as indicated by the GB composition and of the metasomatized metaultramafic rocks with emerald mineralizations, was alkaline, potassic, with a later evolution toward sodic and calcic compositions, Be-bearing, most probably as complex ions with fluorine and carbonate, as well as Al- and Si-bearing (also soluble in alkaline solutions), among others. In the ruptile-ductile shear zones, metasomatic syn-metamorphic reactions of these fluids with the metaultramafic rocks of the vulcano-sedimentary sequences from Capoeirana and Belmont, rich in chromophorous elements ( $\mathrm{Cr}, \mathrm{V}, \mathrm{Ni}, \mathrm{Fe}$, among others), produced the emerald mineralizations of the schist type and the associated emerald mineralizations of the quartz vein/mobilizate type of Archaean age.

The Proterozoic evolution is represented in the study area chiefly by the development of the main event of progressive regional metamorphism and associated deformations. The regional metamorphic grade increases systematically from upper greenschist/lower amphibolite facies in the W, reaching the medium amphibolite facies in the Beimont area and the medium/upper amphibolite facies in the Capoeirana region. This metamorphism caused the progressive reworking of the GB, transforming them into the Foliated Metagranitoids with Fluorite (MGF). These transformations were essentially textural and mineralogical ones, however, preserving almost totally all of the bulk geochemical characteristics, including the positive Be anomaly of the GB in the MGF. The higher regional metamorphic grade in the area $\mathrm{E}$ of the Belmont emerald deposit initiated processes of anatexis and partial fusion in the MGF, producing pegmatoids and pegmatites, some of these beryl-bearing, including the gem variety aquamarine. Intrusive pegmatoids in the metavolcano-sedimentary sequence of Capoeirana (otherwise absent in Belmont) are less deformed than the host rocks and may contain randomly distributed, foliated or folded host rock xenoliths. Where they intrude the metaultramafic rocks, these pegmatoids are frequently emerald mineralized. The pegmatoids represent a Proterozoic event of emerald mineralization of medium to high grade metamorphic origins, related to the initial anatexis of MGF. Possibly the alexandrites from Capocirana - at present unknown from in situ mineralizations and absent in Belmont - were also formed during this event.

The middle and late Proterozoic geological evolution caused only insignificant mineralogical and petrographical imprints in the study area. Except for local processes of rehydratation and weak retrometamorphism, including the formation of epidote, carbonates, chlorite, sericite, that occurred mainly in zones of reactivated folds and fractures.

Some special studies concentrated on the emeralds, distinguishing between the different mineralogical associations and genetic types of these mineralizations (schists hosted, vein quartz and pegmatoid veins). Fluid inclusions indicated the secondary nature and complex composition of the fluid phases. These are $\mathrm{CO}_{2}$-rich in the fluid inclusions, and very $\mathrm{CO}_{2}$-poor in the channel fluids. IR-studies also indicated, that all the studied emeralds belong to the group of emeralds with high alkali contents. 


\section{MIGLIORINI, Renato Blat}

Cemitérios como fonte de poluição em aquiferos. Estudo do Cemitério Vila Formosa na Bacia Sedimentar de São Paulo. 10 de maio. 74 p. Orientador: Annkarin Aurélia Kimmeimann e Silva.

Resumo: $\quad$ Este trabalho constitui parte de um projeto maior que tem por objetivo estudar os impactos gerados pela localização de cemitérios em meio urbano, particularmente no que diz respeito às águas subterrâneas. Esta pesquisa corresponde à fase de monitoramento do Cemitério de Vila Formosa, localizado na área metropolitana de São Paulo, o qual foi escolhido por ser o maior cemitério da América do Sul. Pesquisas paralelas já haviam comprovado a contaminaçăo bacteriológica đas águas subterràneas deste cemitério. O objetivo especifico deste trabalho foi investigar parâmetros indicadores de contaminação química das águas subterrâneas da área do Cemitério Vila Formosa. Para isso foram obtidas amostras de seis poços de monitoramento construidos na área do cernitério e de uma fonte localizada no seu interior. Os resultados das análises fisico-químicas e químicas permitiram as seguintes conclusões:

1. A presença do cemitério contribuiu para elevar a concentração total de íons (sólidos totais dissolvidos) nas águas subterrineas, sendo a fonte mais provável do cátion que mais se elevou $\left(\mathrm{Ca}^{2+}\right)$ a cal utilizada no cemiterio;

2. As águas do Cemitério Vila Formosa apresentaram concentração excessiva de produtos nitrogenados (nitrato, nitrito e amônia), que têm sua origem mais provável no processo de decomposição dos corpos, ativados pela proliferação de microorganismos;

3. A presença do cemitério provocou o aparecimento dos seguintes metais: manganês, cromo, ferro, prata e aluminio, em niveis acima dos valores maximos permissiveis em aguas utilizadas para consumo humano. Estes metais se originam provavelmente das tintas, vernizes e guarniçōes dos caixōes.

Săo enfatizados no trabalhos os riscos de saúde pública representados pela contaminação química das águas subterrâneas de áreas de cemitérios, especialmente pelos altos indices de produtos nitrogenados. São feitas recomendaçőes sobre os critérios de ordem geológica e hidrogeológica que devem ser levados em conta quando da implantação de cemitérios. São ainda apresentados aspectos da incompleta legislaçīo existente sobre o assunto.

Abstract: The present study is part of a larger project designed to investigate the environmenta impacts, in particular the potential risks for groundwaters, generated by the location of cemeteries in urban areas. This work describes the results of physicochemical analyses performed in groundwaters from the Vila Formosa Cemetery, situated in the metropolitan area of São Paulo, which is the largest cemetery of South America. Parallel analyses had already comproved bacteriological contamination of the waters of the water table in this cemetery. The specific aim of the study was to investigate parameters indicative of chemical contamination of groundwaters in the area of Vila Formosa cemetery. To this end periodical samples were obtained from six sampling wells implanted in the area of the cemetery and from a spring located in its interior.

conclude that:

From the results of the physicochemical and chemical analyses it was possible to

1. The presence of the cemetery contributed to elevate the total concentrations of ions (total dissolved solids) in the groundwaters, the likeliest source of the cation which showed the greatest increase $\left(\mathrm{Ca}^{\text {th }}\right)$ being the lime utilized in the cemetery.

2. The groundwaters of the cemetery contained high concentrations of nitrogen compounds (nitrate, nitrite and ammonia), which probably originated from the process of decomposition of corpses, activated by the proliferation of microorganisms.

3. The presence of the cemetery was responsible for the appearance in the groundwaters of manganese, chromium, iron, silver and aluminium in amounts which exceeded the maximal permissible concentrations in waters destined for human consumption. The most probable source of these metals was the paints, varnishes and garnitures of the coffins.

The data obtained in this study emphasize the danger to human health represented by the chemical contamination of groundwaters in areas of cemeteries, specially by the presence of high concentrations of nitrogen compounds. Geological and hydrogeological criteria that should be utilized for the establishment of cemeteries are recommended. Several aspects of the still incomplete legislation on this matter are also presented. 


\section{MONTANHEIRO, Tareísio José}

Estudo comparativo de amostragem em furas de sonáagem e galerias para pesquisa de cassiterita no Pegmatito Xupé - Monte Alegre de Goiás, GO. 27 de maio. 133p. Orientador: Jorge Kazuo Yamamoto.

Resumo: Este trabalho, complementado por documentação geológica đa região do depósito e por uma revisão não só dos métodos clássicos de avaliação de reservas como também dos conceitos e técnicas de amostragem na pesquisa mineral, apresenta os resultados de um estudo comparativo de amostragem em furos de sondagem e em galerias para pesquisa de cassiterita no Pegmatito Xupé, em Monte Alegre de Goiás, GO.

Os corpos pegmatíticos, por exibirem grande variabilidade natural dificultam os processos de amostragem e pesquisa, que, não obstante isso, são de vital importăncia, quando se pensa no aproveitamento industrial dessa fonte de vários metais raros.

Os estudos mostram existir grande diferença de teores médios de estanho nos furos de sondagem e em galeria: basta, para isso, observar a redução constante da variảncia em face da relaçăo fundamental da amostragem: volume $\mathrm{x}$ variância.

Para corpos pegmatiticos constatou-se que a amostragem de grande massa é a mais indicada, e os resultados analíticos de furos de sondagem devem ser vistos apenas como valores indicativos, mas importantes, numa rápida visualizaçăo tridimensional do corpo mineral.

Com os dados levantados no inventário da pesquisa mineral, a avaliação de reservas do Pegmatito Xupé, pelo método dos perfis padrấo, é da ordem de $415000 \mathrm{~m}^{3}$ de minério com $1695 \mathrm{~g}$ de $\mathrm{Sn} / \mathrm{m}^{3}$ e $53 \mathrm{~g}$ de $\mathrm{Ta}_{2} \mathrm{O}_{5} / \mathrm{m}^{3}$.

Abstract: This paper presents the results of a comparative statistic study between drill hole sampling and drift's channel sampling results carried out during the underground exploration and ore reserve evaluation in the Xupé pegmatite - Monte Alegre de Goiás - State of Goiás. The complete geological documentation available in the area, a revision of classical methods for ore reserve estimation and a revision of concepts and techniques of sampling are also presented in this dissertation.

The pegmatite ore bodies usually exhibit a large natural grade variability. In this way the sampling procedures are not easy to accomplish being of capital importance for the appropriate evaluation and industrial use as a source of rare metals.

When both drill hole and drift Sn grade results are compared, large differences of the average grade are noticed. This is true because of the inverse correlation between variance and sample volume which keeps the fundamental relation of sampling: volume $\mathrm{x}$ variance $=$ constant.

It is concluded that bulk sampling is most indicated for $\mathrm{Sn}$ pegmatite ore bodies evaluation and the grade values obtained from drill cores should be used to delineate the tridimensional geometry and ore limits.

$53 \mathrm{~g} \mathrm{Ta}_{2} \mathrm{O}_{5} / \mathrm{m}^{3}$.

Measured and indicated reserves are of the order of $415000 \mathrm{~m}^{3}$, with $1695 \mathrm{~g} \mathrm{Sn} / \mathrm{m}^{3}$ and

\section{PICANÇO, Jefferson de Lima}

Aplicaçăo das sistemáticas Sm/Nd e Rb/Sr no Maciço Itatins (SP). 01 de setembro. 76p. Orientador: Colombo Celso Gaeta Tassinari.

Resumo: O Maciço Itatins, no sul-sudeste do Estado de São Paulo, é uma região composta por rochas cujos protólitos foram incorporados à crosta por volta de $2,5 \mathrm{Ga}$ e que sofreram a ação de epiś́dios de metamorfismo de alto grau e fusão parcial. Compreende as rochas do Complexo Costeiro, representadas pela Suite Itatins e pela Sequencia Cachoeira, as rochas graniticas da Suite Granitóide de Fácies Migmatítica e uma extensa área de rochas migmatiticas intermediárias entre estas duas (Complexo Gnáissico-Migmatítico).

A Suite Itatins compreende dois tipos principais de granulitos: os granulitos tipo Azeite apresentam um comportamento geoquímico empobrecido em litófilos, com baixas razōes $\mathrm{Rb}^{87} / \mathrm{Sr}^{86}$ e os granulitos Guaraú, mais restritos em área, apresentando um comportamento geoquímico enriquecido em litófilos. Ambas as litologias tiveram seu sistema $\mathrm{Rb} / \mathrm{Sr}$ afetados pela granulitizaçæ̃o, gerando diagramas isocrônicos sem significaçăo geológica. 
As rochas da seqüência Cachoeira tiveram seu sistema $\mathrm{Rb} / \mathrm{Sr}$ menos alterado. Os kinzigitos da Ponta da Prainha indicaram idades pré-brasilianas que podem significar uma idade de metamorfismo, ou então idades intermediárias entre a provável geraçāo dos protólitos e o metamorfismo granulitico. Os paragnaisses Itariri indicaram idades brasilianas.

Os migmatitos de Ana Dias forneceram uma idade em tomo de $720 \mathrm{Ma}$, interpretados como idade de migmatização. A paragênese mineral destas rochas é compativel com a formação de fundidos anatéticos em fácies granulito, e a idade obtida reflete a idade da migmatização em fácies granulito.

O sistema $\mathrm{Sm} / \mathrm{Nd}$ apresentou-se mais sensivel ao metamorfismo, através de uma isócrona mineral-rocha total em granulitos tipo Azeite, em paragénese equilibrada em fácies granulito, a qual obteve um resultado por volta de $607 \mathrm{Ma}$. Uma segunda isócrona mineral-rocha total, em paragnaisses próximos a Itariri, obteve $580 \mathrm{Ma}$. As idades modelo $\mathrm{Sm} / \mathrm{Nd}$ (TDM) para rocha total nos granulitos Azeite revelaram idades arqueanas $(2,52 \mathrm{Ga})$. Para os paragnaisses, o parâmetro TDM forneceu uma idade de $1,4 \mathrm{Ga}$, interpretada como uma provável idade de mistura de material das áreas-fontes dos protólitos.

As idades de resfriamento $\mathrm{K} / \mathrm{Ar}$ obtidas para estas rochas estiveram em torno de $580 \mathrm{Ma}$ para as biotitas e $656 \mathrm{Ma}$ para os anfibólios.

As idades $\mathrm{Rb} / \mathrm{Sr}$ de $530 \mathrm{Ma}$, obtidas para os Migmatitos de Mongaguá representam idades de migmatizaçăo em fácies anfibolito. Uma determinação em biotita nestas rochas forneceu valores de $512 \mathrm{Ma}$.

Na datação geocronológica aplicada às rochas granulíticas e associadas que ocorrem no Maciço Itatins, o sistema $\mathrm{Rb} / \mathrm{Sr}$ revelou-se pouco eficaz na dataç̃o de rochas granulitizadas após longa vivência crustal. Jả o sistema $\mathrm{Sm} / \mathrm{Nd}$ em minerais-rocha total mostrou-se bastante apto para datar as paragêneses minerais. Na maioria dos casos envolvendo isócronas granada/rocha total, as idades obtidas săo de resfriamento. Desta forma, idades obtidas nestas isócronas possuem a mesma significação que isócronas $\mathrm{Rb} / \mathrm{Sr}$ em rocha total.

A bstract: The Itatins Massif, in the southeast of Săo Paulo State, comprises the main geological units: a) The granulitic Itatins Suite, subdivided in Azeite granulites, enderbitic-chamoenderbitic, IIIdepleted, and the Guaraí granulites, charnockitic, LIL-enriched; b) The Cachoeira Sequence, composed by kinzigites, kinzigitic gnaisses, anfibolites and calciosilicatic rocks; c) Regional granitic-migmatitic rocks.

The Itatins Granulites have strongly disturbed isotopic systems, with great scatter in the analytical points. The Ponta da Prainha kinzigites record a prebrazilian age of $1.4 \mathrm{Ga}$ in $\mathrm{Rb} / \mathrm{Sr}$ wholerock isochron. The Itariri kinzigitic gnaisses have $601 \mathrm{My}$-old $\mathrm{Rb} / \mathrm{Sr}$ whole-rock isochron.

The Ana Dias Migmatites record a $720 \mathrm{Ma}$ Rb/Sr WR isochron, which gives the age of migmatization. The mesossoma of these granulites, equilibrated in granulite facies, suggests that age is related to the regional metamorphism in granulite-facies conditions.

The Mongagua Migmatites have a $\mathrm{Rb} / \mathrm{Sr}$ WR isochron age of $532 \mathrm{Ma}$. They are located in the Costeiro Block and record a significantly low isochronic age if compared with Itatins Massif ones. Biotite $\mathrm{K} / \mathrm{Ar}$ ages of these rocks record $512 \mathrm{Ma}$.

The K/Ar cooling ages of the Itatins Massif are $590 \mathrm{Ma}$ in biotites and $656 \mathrm{Ma}$ in homblende.

Two Sm/Nd mineral-WR isochrons have been obtained. The pyroxene-plagioclasebiotite-WR isochron recorded $607 \pm 136 \mathrm{Ma}$ from the Azeite Granulites, with $\mathrm{Sm} / \mathrm{Nd}$ model ages $2.52 \mathrm{Ga}$. The garnet-plagioclase-biotite-WR isochron has $508 \pm 22 \mathrm{Ma}$. These ages have been interpreted as an cooling ages of that paragenesis from the granulite metamorphism. Sm/Nd mineral-WR isochrons were more successful to date granulites with previous crustal history after granulitization than the $\mathrm{Rb} / \mathrm{Sr}$ Wholerock isochrons.

\section{SABADLA, José Antonio Beltrão}

Impactos da estocagem de vinhaça e das águas de lavagem da cana-de-açuicar nos dominios do Aquifero Bauru-Dobrada-São Paula 21 de dezembro, 123 p. Orientador: Aldo da Cunha Rebouças. 
Resumo: O presente trabalho apresenta os resultados do monitoramento realizado numa área de aproximadamente $21 \mathrm{~km}^{2}$, no Municipio de Dobrada, centro oeste do Estado de Sāo Paulo, onde foram avaliados os impactos produzidos nas águas subterrâneas e superficiais decorrentes da infiltraçăo e percolação dos efluentes vinhaça e águas de lavagem da cana-de-açúcar, a partir de lagoas escavadas de acumulação e células/tanques de decantação, respectivamente, nos domínios do Aqülifero Bauru (Cretáceo).

O Aqüifero Bauru, livre e poroso, ocorre em uma extensão total aflorante de 104.000 $\mathrm{km}^{2}$, considerando-se somente o Estado de São Paulo, suportando uma demanda atual superior a 15.000 poços com intensa utilizaçăo doméstica e industrial.

Para as águas subterrảneas, o manganès (entre 0,03 e $3,5 \mathrm{mg} /$ ), o ferro (entre 0,45 e 34 $\mathrm{mg} / \mathrm{l}$ ), o alumínio (entre 1 e $52 \mathrm{mg} / \mathrm{l}$ ) e o fosfato (entre 0,03 e $0,38 \mathrm{mg} / \mathrm{l}$ ), ultrapassaram os valores para consumo humano referidos pela Organização Mundial de Saúde (OMS); Decreto n 12.486 de 20/10/78, NTA-60, para o Estado de São Paulo e Resoluçāo CONAMA n 20 de 18/06/86.

Em relação ds águas superficiais, os valores de ferro total ( $3 \mathrm{mg} / \mathrm{l})$ e fosfato $(0,035 \mathrm{mg} / \mathrm{l})$, ultrapassaram os padrōes de potabilidade para consumo humano relatados pelas mesmas referências acima citadas, porém, em valores bem abaixo dos registrados para as águas subterrineas impactadas.

Esta pesquisa pretendeu estabelecer um aprimoramento dos métodos utilizados para a caracterização dos impactos gerados com a infiltração e percolação dos efluentes considerados, destacando as interrelaçōes águas subterràneas/águas superficiais, com o objetivo de prover maiores subsidios à legislaçăo de proteção dos corpos hídricos.

Abstract: This work shows the results of a monitoring carried out in a area of about $21 \mathrm{~km}^{2}$, Dobrada Municipality, Central West region of the State of São Paulo, where the impacts in groundwater and surface water were evaluated by the infiltration and percolation of vinasse and water used for washing cane sugar, through accumulation ponds and decantation reservoirs, respectively, in areas of Bauru Aquifer (Cretaceous).

The Bauru Aquifer, free and porous, occurs in a extended area of $104.000 \mathrm{~km}^{2}$ in São Paulo State, as a major exploitable aquifer (more than 15,000 wells), used for domestic and industrial water supplies.

For the groundwater, the following measures were found in analyses exceeding drinking water standards: manganese $(0.03$ to $3.5 \mathrm{mg} / \mathrm{l})$, iron $(0.45$ to $34 \mathrm{mg} / \mathrm{l})$, aluminium $(1$ to $52 \mathrm{mg} / \mathrm{l})$ and phosphate $(0.03$ to $0.38 \mathrm{mg} / \mathrm{h})$.

For superficial water, the following measures exceeded drinking water standards: total iron ( $3 \mathrm{mg} / \mathrm{l})$ and phosphate $(0.035 \mathrm{mg} / 1)$.

The main purpose of this research is to improve the field methodology to characterize the impacts of vinasse and washing water of cane sugar infiluation/percolation, detaching the relationship between ground and surface water, with the major aim to supply the legislation to protect the drinking water resources.

\section{SALVADOR, Elizete Domingues}

Análise neotectónica da regiäo do Vale do Rio Paraiba do Sul compreendida entre Cruzeiro (SP) $e$ Itatiaia (RJ). 11 de outubro. 157 p. Orientador: Claudio Riccomini.

Resumo: A regiào do vale do rio Paraiba do Sul localizadia entre Cruzeiro (SP) e Itatiaia (RJ), compreendendo o extremo leste da Bacia de Taubaté, oeste da Bacia de Resende, bem como o alto estrutural constituido por rochas do embasamento pré-cambriano que separa estas bacias cenozóicas, a denominada Soleira de Queluz, encerra numerosas evidências de movimentos tectônicos recorrentes, ativos até os tempos recentes.

A análise morfoestrutural, em conjunto com a caracterização dos depósitos sedimentares e das estruturas de caráter rúptil, permitiu o reconhecimento de três fases de movimentaçöes neotectônicas.

Estas movimentaçōes estariam relacionadas inicialmente a esforços compressivos pleistocènicos orientados segundo NW-SE, associadas a um binário transcorrente dextral de direçāo E-W. As estruturas relacionadas a esta fase afetam depósitos coluviais e linhas de seixos, por vezes cavalgados 
por blocos de rochas do embasamento, ao longo de falhas de direçōes preferencialmente NE a ENE. Posteriormente, uma mudança do regime de esforços foi assinalada durante o Holoceno, passando estes a extensionais, com direçăo E-W (WNW-ESE). Esta fase é responsável pela geraçăo de feiçōes marcantes, como gräbens de direçāo $\mathrm{N}-\mathrm{S}$, que embutem pacotes sedimentares com espessuras superiores a trinta metros. Finalmente familias de juntas conjugadas, de direçōes ENE e WNW, seccionando depósitos coluviais, colúvio-aluviais e aluviais, registrariam nova mudança no regime de esforços durante o Holoceno, agora compressivos, de direção E-W, concordante com a direçăo de esforços atuais obtida a partir de dados sismológicos.

O quadro neotectônico já estabelecido é relevante em termos da estabilidade geológica da regiâo, onde estão instaladas grandes obras de engenharia, incluindo uma central nuclear.

\begin{abstract}
The region of the Paraiba do Sul River Valley between Cruzeiro (São Paulo) and Itatiaia (Rio de Janeiro), in Southeastern Brazil, comprises the eastern and western terminations, respectively, of the Cenozoic Taubaté and Resende rift basins, as well as the Precambrian terranes of the Queluz structural high separating these basins, and includes much evidence of recurrent or resurgent tectonic movements that have been active until recent times.

The morphostructural analysis of this region, combined with the characterization of the Quaternary sedimentary deposits and brittle tectonic structures, has permitted the recognition of three phases of neotectonic movements.

The oldest movements were related to a NW-SE compressive stress field, associated with an E-W right-lateral transcurrent binary. The structures related to this phase affected colluvium and stoneline deposits, which are often overthrust by blocks of basement rocks along faults trending NE to ENE.

The stress regime later changed to an E-W (WNW-ESE) extension, responsible for the generation of N-S-trending grabens with syntectonic sedimentary filling.

Finally, a new change in the stress field recorded by conspicuous and widespread families of shear joints, systematically orientated ENE and WNW, that affect colluvium, colluvium-alluvium and alluvium deposits. The acute bisectrix of the families of joints indicate an E-W direction of compression, in agreement with seismological and breakout data.

The reability of the neotectonic data presented in this study and the proposed neotectonic model are particularly significant in that important human activities in the region, including such major engineering projects as a radioactive fuel factory, a hydroelectric power station and reservoir as well as a nuclear power plant.
\end{abstract}

\title{
SANT'ANNA, Lucy Gomes
}

Mineralogia das argilas e evolusāon geológica da Bacia de Fonseca, Minas Gerais, 20 de maio. 173p. Orientador: Johann Hans Daniel Schorscher.

Resumo: A Bacia de Fonseca, de idade eocenica, localiza-se na borda leste do Quadrilátero Ferrifero, Minas Gerais e compreende os depósitos continentais da Formação Fonseca. Os objetivos deste estudo foram a análise da evolução geológica da Bacia de Fonseca no Cenozóico e a mineralogia e petrografia detalhada dos seus depósitos sedimentares com enfoque nos argilominerais da Formaçâo Fonseca.

Os trabalhos geológicos levaram à redefiniçăo da área da Bacia de Fonseca, cujos sedimentos apresentam ocorrência mais restrita do que anteriormente representada nos mapas geológicos da regiẫo. O levantamento de seçôes colunares resultou na apresentaçăo de uma nova seçăo-tipo para a Formaçăo Fonseca, cuja espessura é menor do que anteriormente admitida. Na redefiniçâo da Formaçâo Fonseca foram ainda excluídos os depósitos da Chapada de Canga desta formação.

Os sedimentos da Formação Fonseca são de natureza argilosa a arenosa, maciços a estratificados/laminados, apresentando marcada granodecrescência ascendente. Esses sedimentos foram depositados sob condiçốes de calmaria tectônica e provável clima úmido, em sistema fluvial meandrante.

A Formação Fonseca assenta-se sobre rochas arqueanas do embasamento do Quadrilátero Ferrifero, sendo recorberta por depósitos rudáceos da Chapada de Canga. Estes foram redefinidos como Formaçăo Chapada de Canga, sobrepostos discordantemente ì Formação Fonseca ou ainda, regionalmente, em contatos diretos sobre o embasamento pré-cambriano. Os sedimentos da Formaçáo Fonseca encontram-se falhados por eventos tectônicos trativos que atuaram na área após a sedimentaç̣̄o, 
reativando estruturas preexistentes do embasamento pré-cambriano. Os sedimentos da Formação Chapada de Canga também foram afetados por tectónica trativa, sin-a pós-sedimentar.

Os argilominerais da Formaçấo Fonseca foram caracterizados por diferentes métodos, incluindo análises granulométricas, difração de raios $\mathrm{X}$, microscopia eletrônica de varredura, microscopia eletônica de transmissão com difração de elétrons, análises térmicas, capacidade de troca catiônica e, geoquimicamente, por fluorescência de raios X. Os resultados foram analisados quanto à gênese $e$ significado ambiental dos argilominerais no contexto do ciclo das argilas (erosão, transporte, deposição e diagênese) e quanto à sua relação com a evolução geológica e paleoclimática da bacia.

Os argilominerais encontrados pertencem aos grupos da caulinita, mica e, de forma rara, da esmectita. A caulinita, em parte, e a mica ocorrem como grăos detríticos provenientes de solos das rochas arqueanas da regiaio. Os sedimentos sofreram algum soterramento e a atuação de processos diagenéticos promoveu a neoformação de caulinita em texturas vermiforme e de "livros", além de esmectita, que apresenta-se como grãos placóides ou com forma de "penas".

A atuação do intemperismo acarretou a alteração dos grãos de mica, originando illita nas bordas dos grãos detríticos de mica e dispersa na matriz argilosa caulinítica dos sedimentos.

Em termos de resposta dos argilominerais aos metodos analiticos empregados, ressalta-se a comportamento típico da caulinita, ainda que de moderada ordenaçáo estrutural, mica e esmectita, frente aos estudos com difraçăo de raios $\mathrm{X}$, microscopia eletrónica de varredura e análises térmicas. No entanto, observa-se propriedades atípicas de capacidade de troca catiônica, na qual os resultados obtidos foram mais elevados do que os esperados, o que também se explica mais provavelmente pela baixa cristalinidade e/ou desordem estrutural da caulinita. Os estudos geoquimicos apontaram valores mais elevados para alguns dos elementos analisados ( $\mathrm{Ba}, \mathrm{Cr}, \mathrm{Fe}, \mathrm{Ti}, \mathrm{Zr}$ e V) e baixos teores de $\mathrm{K}_{2} \mathrm{O}$, os quais foram correlacionados, respectivamente, às áreas-fonte $(\mathrm{Ba} e \mathrm{Zr})$, aos argilominerais principais $(\mathrm{Fe}, \mathrm{Cr}, \mathrm{V}) \mathrm{e}$ aos processos intempéricos $\left(\mathrm{K}_{2} \mathrm{O}\right.$ e Ti) que atuaram na área-fonte dos sedimentos.

Abstract: The Fonseca Basin, of Eocene age, is located at the eastern edge of the Quadrilatero Ferrifero ("Iron Quadrangle") in the State of Minas Gerais, Brazil and comprises typically continental sediments of the Fonseca Formation. The present study focuses on the detail mineralogy and petrography of the clay minerals of the Fonseca Formation and their significance in the geological evolution of the basin during the Cenozoic.

Geological mapping has led to the redefinition of the area of the Fonseca Basin based on the distribution of the Fonseca Formation, which showed a much more restricted area of occurrence than previously represented in geological maps. Detailed studies of lithological columns resulted in the establishment of a new type-section of substantially reduced thickness for the Fonseca Formation. The rudaceous Chapada de Canga deposits have been excluded from the redefined Fonseca Formation.

The Fonseca Formation is predominantly argillaceous to arenaceous, massive or stratified/aminated and shows markedly fining-upward grain size. These sediments were deposited during tectonic calm within a meandering fluvial system probably in a humid climate.

The Fonseca Formation rests upon Archean basement rocks of the Quadrilatero Ferrifero and is covered in places by the Chapada de Canga deposits. These have been redefined as the Chapada de Canga Formation, which rests in direct contact upon the Fonseca Formation and, more regionally, upon Precambrian basement rocks. The sediments of the Fonseca Formation were faulted by post-sedimentary events of tractive tectonics that affected the area, reactivating preexisting structures of the Precambrian basement. The sediments of the Chapada de Canga Formation have also been affected by sun- to postsedimentary tractive tectonics. As a result, sedimentary dikes have formed locally.

The clay minerals of the Fonseca Formation have been characterized by grain size analyses, X-ray diffraction, scanning electron microscopy, transmission electron microscopy and electron diffraction, thermal analyses (DTA/TGA), cationic exchange capacity and X-ray fluorescent analytical geochemistry. The results have been interpreted with respect to the genesis and environmental significance of the clay minerals in the context of the cycle of the clays (weathering, erosion, transport, deposition and diagenesis) and their relationships to the geological and paleoclimatic evolution of the Fonseca Basin.

The analysed minerals of the Fonseca Formation include members of the kaolinite, mica, and more rarely, smectite groups. Part of the kaolinite and mica occurs as detrital grains derived from soils of Archean rocks in region. Burial and diagenesis resulted in the neoformation of kaolinite mainly as 
piles of platelets ("face-to-face texture") but also as wormlike aggregates, and of minor smectite as irsegular-platy or "feather"-like crystals.

Weathering altered the mica and caused the neoformation of illite that occurs both along the borders of detrital mica grains and finely dispersed within the kaolinite-dominated argillaceous matrix of the sediments.

In the analyses employed in this study, the response of the clay minerals was typical for kaolinite (in spite of its only moderate structural ordering), mica, and smectite for the X-ray diffraction, scanning electron microscopy and thermal analyses. However, atypical, higher than expected, cation exchange capacities were observed. These most probably can be explained, too, by the low crystallinity and/or structural disorder of the kaolinite. Geochemical studies indicated higher concentrations of some analyzes major and trace elements $(\mathrm{Ba}, \mathrm{Cr}, \mathrm{Fe}, \mathrm{Ti}, \mathrm{Zr}$ and $\mathrm{V})$ and low $\mathrm{K}_{2} \mathrm{O}$ content; these were correlated, respectively, with the source areas $(\mathrm{Ba}, \mathrm{Zr})$, the main clay minerals $(\mathrm{Fe}, \mathrm{Cr}, \mathrm{V})$, and the weathering processes $\left(\mathrm{K}_{2} \mathrm{O}\right.$ and $\left.\mathrm{Ti}\right)$ that acted upon the source area of the sediments.

\section{SIMONETTI, Cristina}

Paleobiologia de sedimentos meso e neoproterozóicos da porção meridianal do Cráton do São Francisco. 24 de novembro. 151p. Orientador: Thomas Rich Fairchild.

Resumo: Esta dissertaçăo, até o momento, o mais detalhado estudo paleobiológico de sedimentos de subsuperficie do Proterozóico brasileiro, apresenta os primeiros registros de microfósseis do Supergnupo Espinhaço e da Formaçăo Lagoa do Jacaré (Grupo Bambui). Os sedimentos, meso e neoproterozóicos, foram selecionados de afloramentos e de testemunhos de subsuperfície do Brasil central (noroeste de Minas Gerais e leste de Gojás). Um total de 66 amostras - das quais, 41 microfossiliferas foram analisadas através de técnicas palinológicas e/ou petrográficas.

Devido à intensa alteração dos afloramentos, apenas nas amostras de silex negro, coletadas nos arredores de Unai (possivelmente do Grupo Paranoá), foram identificados microfosseis significativos. Grande parte dos sedimentos de subsuperficie, ao contrírio dos anteriores, forneceram microfósseis abundantes e, quase sempre, bem conservados; foram selecionados de testemunhos de quatro poços, perfurados na porçăo sul do Cráton do Så Francisco (amostras cedidas pela PETROBRÁS). Nos arredores de Montalvânia e Buritizeiros (MG), três dos poços recuperaram sedimentos meso e neoproterozóicos não afetados pelos dobramentos brasilianos, atribuídos, respectivamente, aos Supergrupos Espinhaço e Săo Francisco. Apenas os sedimentos do quarto poço, perfurado na regiâo cratônica, porém dentro da zona de influéncia da Faixa Brasilia, em Alvorada do Norte (GO), exibem evidências de deformação.

As melhores amostras fossiliferas, com microfósseis diversos e bem preservados, pertencem ao Supergrupo Espinhaço (Gr. Conselheiro Mata) da zona cratónica estável. Constituem os primeiros registros micropaleontológicos do supergrupo. Forma simples, cocóides isolados ou coloniais, com dimensỏes normalmente inferiores a $50 \mathrm{~mm}$, e filamentos tubulares e celulares, com diâmetros variáveis entre 1 e $18 \mathrm{~mm}$, dominam as assembléias fossiliferas.

Dezenove táxons distintos foram identificados nas amostras analisadas. Onze foram atribuidos as Cyanophyceae (cianoficeas ou cianobactérias): Siphonophycus robustum, $S$. kestron, Paleolyngbya sp., Polytrichoides sp., Nostocales 1, Myxocaccoides sp. 1, Myxococcoides sp. 2, Eosynechococcus medius, E. grandis, Chroococcales 1 e Chroococcales 2. Os dernais, de natureza indefinida, foram reunidos na categoria Incetae Sedis: Leiosphaeridia crassa, L ternata, Leiosphaeridia sp. 1, Leiosphaeridia sp. 2, ef. Glenobotrydion, Huroniospora sp., Forma 1 e Forma 2. Todos os táxons apresentam ampla distribuiçåo vertical no Proterozóico, sendo, por isso, pouco úteis nas questöes bioestratigraficas.

A despeito de todas as limitações do registro pré-cambriano, foi possivel associar à quase todas as assembléias um significado paleoambiental, a partir da comparação com microrganismos atuais, principalmente as cianoficeas.

Abstract: This dissertation presents the most detailed paleobiological study to date of subsurface Proterozoic sediments from Brazil, including the first reports of microfossils from the Mesoproterozoic Espinhaço Supergroup and the Neoproterozoic Lagoa do Jacaré Formation. Meso and Neoproterozoic 
sediments were investigated from both outcrops and subsurface of central Brazil (northwestern Minas Gerais and eastern Goiás). A total of 66 samples were analysed by palynological and/or petrographic techniques, 41 proved to be fossiliferous.

As most of the Proterozoic rock outcrops are intensely weathered, only the few silicified sediments collected near Unaf apparently from the Paranoá Group have yielded significant microfossils. On the other hand, diverse microfossits assemblages were identified in most of the subsurface samples . all furnished by PETROBRÁS - from the Southern Săo Francisco Craton. Near Montalvânia and Buritizeiros (MG) three wells provided sediments from the Meso and Neoproterozoic Espinhaço and São Francisco Supergroups, respectively. Only the sediments of the fourth well, drilled on the craton near Alvorada do Norte (GO) within the zone of influence of the Brasilia Fold-Belt, exhibit clear evidence of the Brasiliano tectonism.

The best fossiliferous sediments - with abundant and well-preserved microfossils - are from the stable zone of the Espinhaço Supergroup (Conselheiro Mata Group). This is the first record of fossils in the sediments of that Supergroup. The assemblages are dominated by simple forms represented by isolated and colonial coccoidal microfossils smaller than $50 \mathrm{~mm}$ and by tubular and cellular filaments 1 to $18 \mathrm{~mm}$ in mean diameter.

Nineteen different taxa were identified the investigated samples. Eleven are attributed to the Cyanophyceae (blue-green algae or cyanobacteria): Siphonophycus robustum, $S$. kestron, Paleolyngbya sp., Polytrichotdes sp., Nostocales 1, Myxococcoides sp. 1, Myxococcoides sp. 2, Eosynechococcus medius, E. grandis, Chroococcales 1 e Chroococcales 2. The remaining eight, of uncertain biological affinities are considered as Incertae Sedis: Leiosphaeridia crassa, L. sernata, Leiosphaeridia sp, 1, Leiosphaeridia sp. 2, cf. Glenoboirydion, Huroniospora sp., Forma 1 and Forma 2. All the identified taxa exhibit a broad vertical range in the Proterozoic and thus are not very useful for biostratigraphical purposes.

Despite all the restrictions of the Precambrian paleontological record, it was possible to infer the probable depositional environment of several of the microfossiliferous samples, based on the habit of the analogous living microorganisms (mostly blue-green algae).

\section{TANDEL, Roque Yuri}

Caracterização do Arenito Pirambóia da fazzenda São João em Analândia, SP, e sua utilização industrial. 09 de fevereiro. 75p. Orientador: Evaristo Ribeiro Filho.

Resumo: A mina de areia da Sibelco Mineração Ltda., localizada no Municipio de Analăndia, Estado de São Paulo, foi estudada visando a definiçăo dos principais parâmetros utilizados para caracterizar areias para uso em indústrias de fundiçăo e de vidro. Os trabalhos de campo na área de estudo permitiram o reconhecimento de quatro unidades operacionais: Formaçăo Pirambóia unidade inferior, Formaçăo Pirambóia unidade superior; Formaçăo Botucatu intemperizada e solo de alteraçăo. Ênfase especial foi dada ao solo de alteração que é delimitado por uma linha de seixos (stoneline) que, geralmente, é confundida com o início da deposição do cenozóico por separar solos com algumas carateristicas distintas (cor, porcentagem de óxido de ferro contido e estruturas presentes).

Descreve-se a que a metodologia empregada para análise em laboratório e para a realização de prospeç̧ão mineral. Durante os trabalhos de laboratório foram desenvolvidos dois métodos para determinaçăo do teor da argila $\mathrm{AFS}$, que fornecem resultados similares aos métodos empregados pela Associaçào Brasileira das Indústrias de Fundição (ABIFA) e um método mais eficiente para a verificaçăo do $\mathrm{pH}$ da areia em relaçăo ao empregado pela ABIFA. Estudou-se também alguns fatores que influenciam no $\mathrm{pH}$ da areia e em sua determinaçâo. Com base nos ensaios realizados verificou-se que os sedimentos das formações Pirambóia e Botucatu, após beneficiamento, prestam-se para uso em indústrias de fundiçâa e de vidro.

Recomenda-se o abandono do termo Formaçăo Santa Rita do Passa Quatro por tratar-se do solo de alteraçào do Grupo São Bento. Finalmente sugere-se que as caracteristicas distintas destas quatro unidades informais, descrita nesta dissertação, possam vir a ser empregadas em áreas geologicamente similares.

Abstract: Sibelco Mining Company sand mine, in Analândia district, Săo Paulo, was studied to 
define the main parameters that have been utilized to characterize sand to be used in foundry and glass industries. The field work has showed us the existence of four useful areas: Pirambóia formation inferior member, Piramboia formation superior member, Botucatu weathering formation and alteration soil. Special antention was paid to the alteration soil that is delimited by a stone line. This stone line is normally confused with the beginning of the Cenozoic sedimentation, because it divides soils with some different features such as color, enclosed iron oxide percentage and handy structures.

The methodology that is used in laboratory analysis will be described in this work. During the laboratory work, two methods were developed to establish the rate of AFS clay, these methods afford similar results to those that Associação Brasileira das Indústrias de Fundição (ABIFA) has used, and a method much more efficient to verify the sand $\mathrm{pH}$, than that ABIFA has used. Some factors that has influenced the sand $\mathrm{pH}$ and its determination are also studied.

The essays have showed us that if Botucatu and Pirambóia formation sediments are treated, they can be used in foundry and glass industries. We recommend the abandonment of Santa Rita do Passa Quatro term, in fact, it is São Bento group alteration soil. Finally, we suggest the utilization of distinctive characteristics of these four informal described units to similar geological areas.

\section{TORRES, Fresia Soledad Ricardi}

Floras dass formaçōes Carache e Palmarito (Neopaleozóico), na regiäo de Carache, Estado de Trujillio, Venezuela. 08 de abril. 158 p. Orientador: Oscar Rösler.

Resumo: As formaçôes neopaleozóicas Carache e Palmarito, na região de Carache, Estado Trujillo, Venezuela, apresentam camadas com fósseis vegetais bem preservados. A presença desses fósseis foi primeiramente registrada por Pierce et al. (1961), e preliminarmente classificados por Benedetto \& Odreman (1977a). Odreman \& Wagner (1979) retomaram o estudo dessas tafofloras, mas somente para precisar as idades das camadas onde ocorrem. Embora sem entrar cm detalhes sistemáticos, estes dois últimos trabalhos já observaram que, de acordo com a composição de tais tafofloras, interessantes conclusoles paleobiogeográficas poderiam ser feitas, principalmente pela presença de folhas gigantopteróides no Afloramento de Loma de San Juan da Formaçã̃o Palmarito.

0 presente estudo tem como objetivo principal a análise sistemática detalhada da flora presente nesse afloramento. Foram identificadas as espécies: ?Sphenophyllum sp., Delnortea $\mathrm{cf} D$. abbottiae Mamay et al, Taeniopteris cf. T. multinervis Weiss, Taeniopteris sp., ?Zamiopteris sp. e Cordaicarpus sp.

A espécie Deinortea cf. D. abbortiae Mamay et al., era conhecida somente para a Formação Road Canyon (Artinskiano) no sul do Estado de Texas, como sendo uma gigantopterídea endèmica dos E.U.A.; Cordaicarpus sp., ?Sphenophyllum sp. e Taeniopteris cf. T. multinervis Weiss foram pela primeira vez encontradas em Loma de San Juan.

Cordaicarpus sp. pode estar relacionada com Delnortea cf. D. abbottiae Mamay et al., embora ambas não tenham sido encontradas em conexåo orgânica.

2Zamiapteris sp. já havia sido registrada por Odreman \& Wagner (1979) como membro da tafoflora de Loma de San Juan; manteve-se aqui a reserva quanto à sua classificação.

A partir dessa flora foi possivel concluir, que apresenta fortes relaçōes com as floras do Permiano Inferior do sudoeste e centro-oeste dos E.U.A. Pelas caracteristicas morfológicas das folhas estudadas deduz-se que elas habitaram uma região com regime climático seco, da mesma forma que as floras do Permiano Inferior (Artinskiano) do sudoeste e centro-oeste dos E.U.A., pode-se, portanto, reunir essas floras em uma única formaçåo vegetal quente e seca a qual ocupava a área tropical do centro-oeste do Pangea.

Quanto à idade da tafoflora de Loma de San Juan, pode-se situá-la no Artinskiano, baseado na ocorrência de Delnortea ef. $D$. abbottiae Mamay et al. e pela fauna marinha associada que é semelhante à encontrada nas camadas artinskianas da Formaçăo Road Canyon do sul do Estado de Texas.

Como segundo objetivo desta dissertaçâo foi proposto o estudo sistemático detalhado da flora de um afloramento da Formação Carache, localizado na estrada Carache-Água de Obispo. Assim Sphenophyllum foi encontrado pela primeira vez para o afloramento. Foi confirmada a ocorréncia de Anmularia cf. A. stellata (Schlotheim) Wood, Lobatopteris vestita (Lesquereux) Wagner, Neuropteris ovata Hoffman e $N$. scheuchzeri Hoffmann mencionadas em Odreman \& Wagner (1979). Quanto à idade 
da tafoflora de Água de Obispo, confirma-se a proposta por esses autores, que a situaram no intervalo Vestfaliano D-Cantabriano (Pensilvaniano Superior, limite Moscoviano-Kasimoviano) com base no grau evolutivo de Lobatopteris vestita (Lesquereux) Wagner. A tafoflora em questão tem inegáveis relaçøes a Provincia Floristica Euro-americana.

O terceiro objetivo proposto foi a realização de um estudo sistemático para conferir a presença de Proroblechmum no afloramento de Quebrada Mucuchache (Formaçăo Palmarito) em camadas de idade asseliana (Permiano Inferior). Com base no estudo do único cxemplar disponivel foi confirmada a presença do gênero, podendo corresponder à espécie $P$. wongii Halle.

Floras semelhantes com a do afloramento da Formaçăo Carache são conhecidas na Argélia e no Marrocos, em camadas de carvão do Pensilvaniano Superior, as quais também podem ser incluidas na Provincia Florística Euro-americana.

Por outro lado, no Permiano Inferior, flora na Venezuela e no Marrocos são conhecidas e não possuem ambas relaçôes com nenhuma outra do Gondwana ocidental, mas sim tem claras afinidades a primeira com a formação tropical seca do sudoeste e centro-oeste dos E.U.A., e a segunda com a Provincia Floristica Euro-americana.

A porcāo norte do Gondwana ocidental no Neopaleozóico localizava-se nas latitudes baixas do hemisfério sul $\left(0^{\circ}\right.$ a $\left.23^{\circ}\right)$. Dentro dessa área, encontravam-se a Venezuela, a Argélia e o Marrocos, nela é possivel encontrar tafofloras relacionadas com a Província Florística Euro-americana no Pensilvaniano Superior e tafofloras do Permiano Inferior diferentes das conhecidas dentro da Flora de Glossopteris, mas sim relacionadas com outras floras bem conhecidas na faixa equatorial do Pangea; desta forma, é possível propor a existência de um Gondwana tropical durante o Neopaleozóico.

\begin{abstract}
The Neopaleozoic Carache and Palmarito Formations, in the Carache region, Trujillo State of Venezuela show beds with well preserved fossil plants. Although only preliminary reported (Pierce et al., 1961; Benedetto \& Odreman, 1977a; Odreman \& Wagner, 1979) their importance for paleobiogeographic discussions, particularly by the presence of Gigantopteris-like leaves in the Palmarito Formation, was already pointed out.

As a result of the present detailed systematic study, mainly based on new collected samples, at the Loma de San Juan outcrop (Palmarito Formation) in the Carache region, the following taxa were identified: 2Sphenophyllum sp., Delnortea cf. D. abbottiae Mamay et al., Taeniopteris cf. $T$. multinervis Weiss, Taeniopteris sp., ?Zamiopteris sp. e Cordaicarpus sp.

Delnortea abbottiae Mamay et al. was know as occurring only in the Road Canyon Formation (Artinskian) in Southern Texas, as an endernic gigantopterid of the U.S.A.; Cordaicarpus sp., ?Sphenophylhm sp. and Taeniopteris cf. T. multinenvis Weiss are here first reported and described for this locality.
\end{abstract}

Though not yet found in organic connection Cordaicarpus sp. and Delnortea cf. D. abbottiae Mamay et al. could be related to the same plant.

?Zamiopteris sp. is here confirmed (but with the same caution in the identification) for the Loma de S. Juan outcrop.

This composition has revealed close relationship to Artinskian floras of Central-Western U.S.A. Both present morphological fearures which suggest adaptation to dry environmental condition. It is possible that this vegetation was distributed along all the dry tropical climatic belt of the Central-West Pangea.

The Artinskian age for these beds is suggested not only by Deinoriea but also by the marine invertebrate fauna found at the same localities.

A second venezuelan flora (Água de Obispo, Carache Formation) is also here studied in detail. Sphenophyllum is here first reported for this locality and the following taxa were confirmed: Anmiaria cf. A. stellata (Schlotheim) Wood, Lobatopteris vestita (Lesquereux) Wagner, Neuropteris ovata Hoffmann and Neuropteris scheuchzeri Hoffmann.

The age of Agua de Obispo flora is confirmed as ranging from Westphalian D and Cantabrian, on the basis of evolutive stage of Lobatopteris vestita (Lesquereux) Wagner, as proposed by Odreman \& Wagner (1979). This flora shows clear relationship to those of the Euramerican Province.

This study also confirmed the identification of Protoblechnum of the Quebrada Mucuchache (Paimarito Formation, Asselian) based on the only specimen already studied by Odreman \& Wagner (1979). 
This floral distribution and relationships is here discussed. It is concluded that the floras of low latitudes of the West Gondwana are distinct of those of the interior of this paleocontinent but with closer relationships with those of the tropical region of Pangea.

Thus, a North-West Gondwana tropical region during de Late Carboniferous and Early Permian is here proposed. 